\title{
Exile, Modernity, and Cultural Patriotism
}

\author{
The Convergence between Exile and Modernity
}

Coming to terms with the modern world was for Tang Junyi not simply a matter of emulating or criticizing the West or appraising the relevance of Chinese intellectual, social, and cultural traditions for contemporary societies. Nor is Tang's thought confined to juxtapositions of Chinese culture and Western civilization, of traditional and modern world-views, or of urban life styles in industrialized countries and the remnants of traditional life patterns in modernizing countries. Tang's philosophical reflection on social modernity goes beyond such schematism and entails a much more ambitious agenda which comprises a cosmopolitan notion of cultural patriotism that is set within a post-colonial "East Asian" context. But above all, there is a bold attempt to fathom the significance of the exilic condition in relation to the process of modernity as he perceived it in the mid-2oth century. The post-1949 exile thus acquired a new meaning as a specifically modern experience. In his writings on the condition of exile, Tang often described the hardships of emigration in a manner that is similar to the way he depicted the fate of modern man, whom he found to be displaced, deracinated, and socially isolated. As will be discussed, Hong Kong for him was just as much a symbol of exile as it was a representation of the disenchanted, reified world of modernity. The exilic experience coincides here with and even reinforces the downsides of "modernization" (xiandaihua 現代化). ${ }^{1}$ It is hence no exaggeration to say that this perception of the modern world is shaped by his profound experience of exilic life in Hong Kong after 1949. In order to explore this relation between exile and modernity, and especially the intersecting descriptions of their downsides, Tang's perception of social modernity will be taken as a point of departure.

What has been called elsewhere "the dual character of the fundamental experience of the modern" 2 is clearly evident in Tang's discussion of modernity. This dual character encompasses two intertwined aspects of the individuals' lives in modern societies: on the one hand, their experience of liberation from religious and traditional restraints leading to social, political, and intellectual

1 The term "xiandaihua" is used rather seldom by Tang; see e.g. Zhang, Zhongguo wenhua yu shijie, p. 33 .

2 Rosa, Identität und kulturelle Praxis, pp. 17, 308-309. 
emancipation, and, on the other, the dissolution of communal ties and the disintegration of traditional social and political values, triggering feelings of intellectual isolation and social alienation. Tang made a number of observations about modern life consistent with this diagnosis while travelling in the United States in 1957: Individuals, while enjoying increasing freedom in joining diverse social, economic and cultural associations, also face the peril of such forms of particularity. To use Tang's expression, they can lose sight of and become indifferent toward "universal ideals of humanity." If this tendency continues unabated in America and elsewhere, the outcome would be a global degeneration of freedom. The "transcending, comprehensive spirit" of humanity might then decrease on a daily basis and with it, the desire for establishing the freedom of humanity. In spite of his sometimes very blunt criticism of what he perceived as the detrimental social impact of rampant egotism in the United States and Western societies in general, Tang did not qualify these tendencies as a specifically Western phenomenon. It is rather a case of a global, but also inevitable consequence of the progressive division of labor and specialization in production, science, technology, and education. This might lead to the gradual replacement of an "objective consciousness of values" by "outer values of efficiency" which would leave individuals unable to grasp the "inner value" of their work. What is at stake, in other words, is nothing less than the increasing "reification" (wuhua 物化) of the human being. ${ }^{3}$

Tang restated his dire diagnosis of modern man's reification in various texts from the 1950s to the 1970s. In a particularly succinct passage from an article on "World Humanism and Chinese Humanism" from 1959, he maintained that since humanity has lost control over the things it produces in affluent societies, a severe threat has emerged for Eastern and Western humanism, and even for humanity itself. This threat entails a surfeit of science and technology resulting in the production of weapons of mass destruction, as well as a severe spiritual crisis among urban citizens who live isolated, empty lives. Finally, a "hitherto unknown" "scientification" of modern political organizations might occur and lead to the establishment of highly rigid organizations in which the individual merely figures as a statistical number, unable to exert the "freedom of a spiritual life." Tang depicted two types of materialism from a global perspective that have emerged in this context:first, Soviet-style communism, which produced a

3 Tang, Zhonghua renwen yu dangjin shijie, Vol. 8, pp. 111-112. Tang did not elaborate on his use of the old expression "wuhua," which can be found for example in Zhuangzi, Chap. 2. For an example of Tang's attack on selfish individualism in the United States, see one of his articles in the Mingbao from 1974: Ibid., pp. 425-426. 
"conceptual materialism" that locks human beings in an "intellectual cage" and triggers a "comprehensive reification of man;" second, the materialism found in the large cities of America and Europe, where a "behavioral materialism" effectuates the calculation of all human values against monetary standards. Both types of materialism coincide in their negative effect of depriving human beings of their subjectivity. Any solution to this crisis must therefore consist of enabling the human beings to "magnify themselves" and to spiritually rise above the sphere of material production. ${ }^{4}$

Tang's concept and diagnosis of modernity do not lend themselves to the romantic idea of a swift return to pre-modern humanistic traditions as an escape from the reifying tendencies of the modern world. This is also evident from his reflection on the basic structure of modern society: According to Tang, it is characterized by an increasing differentiation of institutional and ideational/value-based spheres (i.e. law, art, morality, science). The "principles of societal organization" are hence such that the integration of and within these spheres is not realized through substantial traditions anymore, but contracts and laws. ${ }^{5}$ By taking the stratified, functionally differentiated societal structure as constitutive of social modernity, this conception is reminiscent of Max Weber's discussion of the "rationalization" of "occidental" culture leading to a functional "differentiation of 'spheres of values' (science, law, morality, art) that held their own particular 'logic of judgments about facts, justice or taste."' ${ }^{6}$ Tang and the co-authors of the manifesto of 1958 found China lacking in this regard and consequently proposed that a modern Chinese society would need a firm institutional differentiation of spheres of values. The manifesto stated accordingly that an individual's self-awareness and actions should not be solely related to the sphere of moral demands:

We say that Chinese culture, in accordance with its own demands, should deploy a cultural ideal of driving the Chinese not only to self-consciously [recognize] their self as a "subject of moral practice" on the basis of the [Confucian] study of mind and [human] nature (xin xing zhi xue

4 Ibid., pp. $55^{-56}$.

5 Ibid., p. 136.

6 For the quotations: see Habermas on Weber in: Habermas, Der philosophische Diskurs der Moderne, p. 206. Tang might have been familiar with Weber through the work of Talcott Parsons; on the significance of Parsons for the Chinese reception of Weber in the 1950s: see Gransow, "Die chinesische Rezeption des Werkes von Max Weber oder Fremdverstehen and Selbstverstehen als Kategorien der Chinaforschung," p. 63 . 
心性之學). [The Chinese] should, at the same time, in politics strive to attain the ability to self-consciously [recognize their self] as a "political subject," and in the realms of nature and knowledge, [they should strive to] become an "epistemological subject" and a "subject of the activities of applied technologies." This is also to say that China needs a truly democratic national reconstruction as well as science and applied technologies. In Chinese culture, [we] must accept Western, or global cultures. (...) [This] will drive the personalities of the Chinese to attain an even higher perfection. The objective spiritual life of the Chinese nation [will thus] attain an even higher development. ${ }^{7}$

Against this backdrop, the manifesto leaves no doubt that a modernizing China needs to conform to the ostensibly global structural outline of social modernity, even at the cost of abolishing traditional patterns of social and moral thought:

If the Chinese want to possess this Western spirit of the theoretical sciences, then it is, in turn, indispensable that the Chinese are able to temporarily restrain their practical activities and moral goals. But since the end of the Ming Dynasty, this point was never clearly grasped by [Chinese] thinkers. $^{8}$

Overall, one may conclude that the concept of a functional and institutional differentiation of spheres of values in modern society is indeed a normative reference for the whole modern Confucian project of China's humanistic "reconstruction."

This reconstruction would require a broad range of efforts in modernization. The manifesto of 1958 bluntly states that industrialization in China had not yet reached a sufficient level, and the same is said to hold true for the development of modern science and technology in general. The deficits in democratic politics are also diagnosed as symptoms of failing modernization: Democratic institutions faltered already right after the promulgation of the republic in 1912 when representative government crumbled, leaving the plurality of social interests without a political voice, and denying local autonomy an adequate standing. Apart from these institutional failures, the

7 Zhang, Zhongguo wenhua yu shijie, pp. 32-33.

8 Ibid., p. 35; on the differentiation of politics, ethics, religion in Western civilization and their conflation in Chinese history see ibid., p. 18. 
manifesto deplores the fact that there were only very vague "notions of people's rights and democracy" among the people. ${ }^{9}$

Yet the crisis that had to be addressed by the Confucian project of reconstruction was even more severe. It had effects that went far beyond the above-mentioned, current deficits in Chinese modernization-effects that were already observable in the West. In order to understand why Tang was convinced that this mattered to China, one needs to recall that he conceptualized modernity as a globally ongoing process of modernization. He elucidated this concept in a paper entitled "The Reconstruction of Confucianism and the Modernization of Asia," which he presented in July 1965 in Seoul at the "International Conference on the Problems of Modernization in Asia." Furthermore, he pointed to what he believed would eventually emerge as the general direction of modernity, namely, the formation of nation-states in the political form of liberal democracies that safeguard fundamental human rights, complete with a scientific-technologically progressive, industrialized society. ${ }^{10}$ This anticipation of a global convergence in modernization is clearly in line with the mainstream of modernization theories which had reached their climax in the United States in the 1950s and were prevalent in social sciences well into the $1960{ }^{11}$ Whether Tang had actually studied such theories in-depth is unclear-after all, his own reflection on modernity has a rather weak footing in social science-but it is still likely that he had acquired some general knowledge of them. Be that as it may, it is this perspective of convergence that allowed him to depict China's historical development since the mid-19th century not as an aberration or anomaly of modernity, but as an integral, albeit temporally distinct, evolution within the modern world. The modern Chinese nation-state, in other words, was, like its Western counterparts, still in the making, albeit with a considerable backlog. Tang, however, did not share the common assumption of American modernization theories that a market-induced type of (originally Western) modernization would by necessity, sooner or later, effect similar political and cultural transformations in societies across the world. He thus also did not expect that cultural particularities would be eliminated or rendered altogether irrelevant in the course of modernization. Even though modernization, according to Tang, entails strong universal tendencies, it still allows, as an incomplete global process, for culturally particular manifestations. Nor did Tang subscribe to the general view that

$9 \quad$ Ibid., pp. 41-42.

10 Tang, "The Reconstruction of Confucianism and the Modernization of Asia," p. 361; see also an interview from 1974: Tang, Zhonghua renwen yu dangjin shijie, Vol. 8, p. 312.

11 Knöbl, Spielräume der Modernisierung, pp. 11-12, 30-32. 
there exists an insurmountable chasm between modernity and tradition. $\mathrm{He}$ rather anticipated that Asian societies eventually succeed in securing the coexistence of modernized and tradition-based social subsystems. ${ }^{12}$

In spite of this generally optimistic outlook, Tang did not expect that China would easily escape the dangers of modernity that were already threatening Western societies. It would not be feasible for the Chinese to simply side-step the downsides of Western-type modernization and implement only those selected parts that seemed to have been beneficial to Western societies. The open-ended global process of modernization described by Tang is too dynamic to be reduced to such a scheme. Nor would this scheme be consistent conceptually with Tang's ambition to outline a Confucian reconstruction for addressing global problems of modernization. This ambition is evident, for example, in the manifesto of 1958, which claims that the project of modern Confucianism is significant in terms of a world philosophy.

It is against this backdrop of global concern that Tang turned to the problem of mankind's submission to the instrumental rationality fortified in the capitalist economy and the modern bureaucratic state - a criticism that was also expressed by Max Weber and other Western theoreticians on modernity. Tang warned of the coercive nature of an instrumental modernity and the dangers of mankind's reification, calling attention to the "new bondage" which humanity experiences in "the modern industrialized community" and the "new slavery in the modern social and political systems." He saw modern man in the figure of an uprooted, socially isolated city dweller and worried that freedom and equality in modern societies are in danger of becoming simple formalities which have no practical repercussions for social relations. In a sober conclusion, he observed that, due to the progressive dissolution of family structures, it will be difficult for the modern individual to develop a moral personality according to the Confucian ideal. ${ }^{13}$ Modern man and the émigré thus share the predicament of having to reconstruct a social context of common values in a situation where considerable parts of their lifeworld, including binding traditions and conventions, have dissolved. When the place of emigration is a rapidly modernizing society like Hong Kong, the disorienting effects of the forceful nature of modern rationalization and emigration

\footnotetext{
12 This alignment of Tang's concept of modernization is to some extent in accordance with Tu Wei-ming's introduction of the concept of multiple modernities to the Chinese and East-Asian context; see Tu, "Multiple Modernities-Implications of the Rise of 'Confucian' East Asia.”

13 Tang, "The Reconstruction of Confucianism and the Modernization of Asia," pp. 370-371.
} 
converge and are felt even more keenly. Tang addressed this convergence by conceiving a type of normative reintegration in modern/exilic society that might be achieved without taking a harmful shortcut in traditionalism - that is, without haphazardly proclaiming the ostensibly healing effect of a return to communal life dominated by a substantial ethos, religion or mandatory set of virtues.

The general assumption of Confucianism about modernity is that even though modernity has a forceful nature, it is not characterized overall by inevitability. Thus modernity retains, according to modern Confucianism, its optional nature as a project of modernization. This project can largely be guided by normative inputs stemming from shared political convictions, moral standards, and cultural conventions. ${ }^{14}$ The predominance of structural constraints and instrumental rationality over humanistic cultural resources in modern society is therefore not seen as an inevitable outcome of modernity, but rather as a manageable deficiency. This perception of modernity leaves room for hope-however dwindling it may be — that "culture" can be liberated from the rampant, blind consequences of an all-pervasive socioeconomic professionalization, fragmentation, and reification. To this end, the historical evolution of such negative consequences of modernity must be made intelligible. ${ }^{15}$ This expectation is in stark contrast to Weber's famous diagnosis of an administered society, in which shared values and norms are regularly restricted by the inner workings of instrumental rationality. In depicting modern society as an "iron cage of dependence" that is forged by the modern bureaucratic state and the capitalist economy, and from which no human agent, whether individuals or collectivities, can ever escape, Weber's outlook is unavoidably pessimistic. ${ }^{16}$ His diagnosis of an irreversible disempowerment of historical subjectivity in the course of modernity thoroughly discredits any notion of human agents acting as helmsmen of their own history.

Just the same, Tang's modern Confucianism is not naively optimistic to the point of proclaiming that the predicaments of modernity may be eradicated as such, once and for all, by concerted human action. Consequently, Tang remained critical of ideas concerning a substantial reconciliation of all inner contradictions in modern societies, as, for instance, Kang Youwei's notion of a homogeneous world state of "Great Uniformity" would have it (see below).

\footnotetext{
14 Ibid., pp. 370-371.

15 Tang, Zhonghua renwen yu dangjin shijie bubian, Vol. 10, pp. 392-393.

16 For a concise analysis of Weber's modernity theory, see Habermas, "Konzeptionen der Moderne," pp. 208, 212; and Sandkühler, “Säkularisierung/Modernisierung," pp. 166-167.
} 
Nor did he propose a model for a traditionalist infusion of modern society with pre-modern, communal forms of collective life. Rather, the modern individuals are to be enlightened to the increasing contradictions between, on the one hand, their subjective inwardness, dispositions and feelings and, on the other, the objective modern world, which is the outcome of an irreversible historical process. Calls to substantially reintegrate the different ethical, political, economic, and cultural roles (or "subjectivity") of individuals in modern societies would thus be futile. Therefore, a final reconciliation of subjectivity and objectivityof spiritual inwardness and "outer," "objective" social, economic, legal, political, and intellectual relations - is unattainable in the modern world, ${ }^{17}$ as much as exile is an inextricable, fateful state of existence for those who have to emigrate. The very form of modern and exilic life is hence characterized by alienation.

The fundamental, albeit implicit, message of Tang's reflection about modernity and exile may be summarized as follows: if the individuals can fathom the inner workings of modernity and exile, they might then be able to see through and grasp their own experience of alienation as the historical form of the modern world. This insight would mitigate the experience of alienation somewhat. But Tang did not demand from the individual a complete submission to an alienated form of life. Instead, he assumed that, based on a reflective grasp of modernity and exile, there might emerge, if not a perfect modern society, than at least a society whose members retain the freedom to strive for their own spiritual perfection. Against this backdrop, his modern Confucianism aimed to reconstruct ideational inputs - political, social and ethical ideas, values and norms, religious convictions, and historical consciousness - that are conducive to breaking up the dominance of instrumental rationality in modernizing societies. This endeavor, a crucial part of which involved a critical reconstruction of "humanistic culture," could just as easily take place in exile.

The exilic setting of this endeavor had far-reaching implications. Tang deemed the Chinese nation-states on the Mainland and on Taiwan both unfit to live up to the democratic promises of their respective republics and, hence, to fulfill an integral requirement of a modern nation-state. ${ }^{18}$ For all its constraints, the place of exile was well-suited to reconsidering the foundations of modern China. After all, whereas the regimes on both sides of the Taiwan Strait

\footnotetext{
17 With respect to the concept of modernity, Tang's thought is here in line with Hegel's; see Ritter, Metaphysik und Politik, p. 215.

18 For Tang, the true "Republic of China" (Zhonghua Minguo 中華民國), that is a "democratic Chinese nation-state," had not been established so far, but is a state in the making; see Tang, Zhongguo renwen jingshen zhi fazhan, pp. 175-176.
} 
curtailed the social and political deliberation about modernization, the condition of exile, for all its restraints, opened up a discursive space for an undogmatic approach to China's modern problematic. According to the authors of the manifesto, the experience of emigration and exile was the decisive catalyst for their attempt to reconsider "the problems of China" in the modern world (see below). Yet this positive outlook on the exilic situation cannot betray the fact that Tang experienced exile first and foremost as an intellectual and historical void.

\section{Exile as Horror Vacui}

Tang published two long essays at the beginning of the 1960 s in the periodical Zuguo Zhoukan which were entitled "On the Fall and Demise of the Flowers and Fruits of the Chinese Nation - on the Meaning and Value of Conservation and a Message for Persons Overseas," and "The Fall and Demise of the Flowers and Fruits and the Planting of a Holy Tree through the Self."19 Earlier, Tang had spoken only in isolated moments about exile, above all in the second half of the 1950s. Specific examples can be found in his address to students at the beginning of a new term of study at the New Asia College, in shorter articles in journals and in the above-mentioned manifesto of $195^{8}$.

From the exilic perspective, Tang depicted Hong Kong as a non-place in the sense of Marc Augés anthropological theory of supermodernity. The city was an alienating habitat, where individuals no longer recognize themselves because they cannot situate this place in their own historical, biographical, and generational narratives. Following Augé, Hartmut Rosa sees this particular deepening of inter-generational alienation as a sign of the modern transformation of places into non-places. ${ }^{20}$ Neither Augé nor Rosa considers the condition of exile, however, which indeed may be depicted as a paradigmatic non-place. It is significant that Tang, in contrast to Augé, traced the reasons for the

19 "Shuo Zhonghua minzu zhi hua guo piaoling—jian lun baoshou zhi yiyi yu jiazhi bing jinggao haiwai renshi 說中華民族之花果飄零一兼論保守之意義與價值並敬告海 外人士," Zuguo Zhoukan, 35, No. 1 (1961); "Hua guo piaoling ji linggen zi zhi 花果飄零及 靈根自植," Zuguo Zhoukan, 44, No. 4 (1964). Both essays were published in book form in 1974, together with a reprint of the manifesto of 1958 and two sets of lecture notes which had been published earlier in Mingbao Yuekan 明報月刊: Tang, Shuo Zhonghua minzu zhi hua guo piaoling.

Augé, Non-lieux, p. 100, cf. also: Rosa, Identität and kulturelle Praxis, pp. 205-206. 
divisions between generations in daily life not only back to modern phenomena of accelerated social change, but also to exile. Ultimately, the exiles in Hong Kong society experienced isolation in their daily life due to the singular event of their emigration. This was further exacerbated by the experience of intellectual, personal, and biographical isolation, which at least tacitly separated the exiles from the non-exiled generation of their parents and from the succeeding generation of youngsters, who were born in Hong Kong and had not experienced emigration. In other words, the exiles constitute a generation unto themselves. Since their horizon of experience is hallmarked by their experience of emigration, they are separated from the older and the younger generations by a deep gulf. In this insular, exilic present, in which common inter-generational contexts are by and large lost, the emigrants face the danger of being unable to express their own personal identity in the contexts of shared values, lifestyles, and common cultural practices. The exilic self, possibly even more so than the modern self, is required to establish new value horizons and normative links from within the self. In the process of doing so, the individual is inevitably confronted with a new, puzzling plurality of horizons of meaning and lifestyles. This, in turn, hampers the stabilization of his or her personal identity within common horizons of cultural meaning.

It is significant therefore that Tang Junyi, Xu Fuguan, Mou Zongsan and Zhang Junmai describe the start of their exile as an experience of intellectual and emotional isolation and emptiness, in which they "looked around to all sides and saw only endless distance."21 Tang's description of the exile is not always lyrical, in some places his language is distinctively declamatory: His vocabulary includes terms such as "native soil," "homeland" or "motherland," terms that smack of a lingering nationalist chauvinism. It is important to bear in mind here, however, that such expressions do not have the same historical baggage in the Chinese context as they do in European languages. As will be demonstrated, Tang's language is not that of a nationalist, but rather of a conservative patriotic thinker. At times, for example when he confessed his yearning for the landscapes he loved when he still lived on the Mainland, there is a coincidental, but all the same illustrative, consistency between his emotional writing style and the way cosmopolitan philosophers of the European Enlightenment expressed their own patriotic fervor. If nothing else, this congruence reminds us that cosmopolitanism and patriotism are not mutually

21 Zhang, Zhongguo wenhua yu shijie, p. 4. The wording quoted here comes from a poem attributed to the Ming loyalist Zheng Chenggong 鄭成功 (Koxinga 國姓爺; 1624-1662) who retreated to Taiwan with his remaining forces when the Ming cause was finally lost on the Chinese Mainland after the establishment of the Qing Dynasty in 1644. 
exclusive. Lao Sze-kwang was therefore mistaken when he suggested that Tang, in professing his longing for the mountainous landscape of his youth in his later writings, displayed a "national-cultural" consciousness and "love for tradition" together with a "strange" yearning for the reconciliation of human values with the "old society."22 Rather, Tang expressed here an emotional attachment to the landscape of his youth and an alienation from his place of exileHong Kong.

Tang Junyi perceived Hong Kong from an anti-colonial perspective as a "colony of Englishmen" which had, as he explicitly stated, no more significance for him as "our land" than the English had as "our people."23 At the same time, he described Hong Kong as a center of business and trade, in which the eminent spheres of "humanistic culture" - ethics, philosophy, art, music, literature and religion - have barely been developed. It was to him, to a certain extent, a historically empty place where neither historical époques nor intellectualhistorical dimensions of culture could be experienced. He thus posed the following rhetorical question to the students of the New Asia College at the beginning of the new term in September 1959: "What intellectual ties do you have to 'Hong Kong'?" According to Tang, in Hong Kong there were only ties related to tycoons and businessmen from industry and trade. Hong Kong, in his view, was meaningless, since there were no notable libraries, museums, academic symposia or societies to be found. The only things available were traded goods from all the world's leading countries. ${ }^{24}$

Here, Tang painted a picture of a creeping, intellectual, emotional and practical colonialization of the lives of the exiles, a process that went hand-in-hand with their acclimatization to the emptiness of the non-place "Hong Kong." The historical and cultural awareness of the emigrants as a community of exiles is permanently at risk of becoming gradually dispersed under the colonial conditions of life, until the emigrants finally forget where they have come from and how they came to find themselves suffering from colonial repression. Against this backdrop, Tang assigned the exiles in Hong Kong and Taiwan the task of keeping alive the consciousness of their community-a community that was bound by a common fate in the face of a Chinese populace of Hong Kong, which accepted the colonial situation as an everyday reality. It is out of such concern

22 Lao Siguang (Lao Sze-kwang), "Cong Tang Junyi Zhongguo zhexue de quxiang kan Zhongguo zhexue de weilai," p. 21.

23 Tang, Shuo Zhonghua minzu zhi hua guo piaoling, p. 29; cf. ibid., p. 43. Tellingly, Tang wanted to be laid to rest in Taiwan, not in Hong Kong, and explained this by stating that Taiwan was native soil; see Tang, Nianpu, p. 217.

24 Tang, Zhonghua renwen yu dangjin shijie bubian, Vol. 9, pp. 505-506. 
that Tang, in 1956, observed that it is not only those students of the New Asia College born in Hong Kong who appear to have no interest in the problems of Chinese statehood, nationhood and humanistic culture. In fact, the "youth" and "high-ranking intellectuals" who are essentially living in "exile" (liuwang 流亡) are by now also experiencing noticeable difficulties in recognizing their responsibility in these matters. ${ }^{25}$ In Tang's view, this change in mindset had taken place between the mid-1950s and the beginning of the 1960s. Not only in Hong Kong, but also in Taiwan, South East Asia, Europe and America, many "compatriots overseas" gradually came to terms with "living far away from home." ${ }^{26}$ Such a transformation is also evident in Tang's conclusion that only a steadily decreasing number of emigrants still experiences exile as an anomaly to be suffered. ${ }^{27}$ Thus, even within the generation of exiles, there are those emigrants who become increasingly oblivious to their status of exile and gradually adapt to a normalized everyday life in spite of the colonial circumstances. Emigrants like Tang consequently felt increasingly isolated as an exiled generation, sharing a particular horizon of experience that is specific to their lifetime. We may assume that the related feelings of social isolation, atomization and marginalization turned exilic space even more into a non-place.

One of the core experiences of exile is undoubtedly the fact that answers to the question of origin within exile circles no longer seem so unambiguous. A wide range of identification with "China" as a place of origin comes to the forefront and, along with it, the possible diversity within such an identification. In the 1950s and 1960s, Tang thus continued to speak consistently of "China" as Zhongguo 中國 or-with stronger cultural connotations-Zhonghua 中華 as the place of origin of Chinese living outside the Mainland. But, at the same time, he employed a more differentiated terminology. In Taiwan and Hong Kong, there was a “Chinese youth" (Zhongguo qingnian 中國青年) and a Chinese society, which he termed Huaren shehui 華人社會 (society of Hua people) or Zhongguoren zhi shehui 中國人之社會 (society of the Chinese). ${ }^{28}$

25 Ibid., pp. 428, 431. Origins also play an important, although secondary role here. Tang notably pointed out that Chinese people born in Hong Kong "originally come from the Mainland:" Ibid., p. 432.

26 Tang, Shuo Zhonghua minzu zhi hua guo piaoling, p. 1.

27 This use of the term "generation" follows sociological work in the field of migration research, whereby immigrants are categorized as "first generation", and those born to immigrants are known as "second generation:" Pan, The Encyclopedia of the Chinese Overseas, p. 17.

28 In today's language usage, "Zhongguoren" sometimes has connotations of nationality (People's Republic of China or Republic of China) and "Huaren" ethnic and/or cultural links to "China;" Tu, "The Periphery as the Center," pp. 25-26. In Tang's writings, the 
For Chinese communities in other countries, he used the term "societies of Chinese sojourners" (Huaqiao shehui 華僑社會), which clearly has much weaker national-cultural connotations. ${ }^{29}$ Characteristic of these societies of overseas Chinese is a situation in which old traditions and customs are hardly maintained. ${ }^{30}$ This situation, however, is not indicative of an emancipatory, gradual dismantling of oppressive traditions, but much more a symptom of increasing repression in places of emigration. In Tang's view, Chinese communities in the Philippines, Indonesia, Vietnam, Malaysia, Singapore and Burma continued to be disadvantaged culturally, politically and economically. No less troubling was the fact that the "Chinese youth" from Taiwan and Hong Konghe was thinking here in the first instance of the educated elite-had been dispersing across the globe for some time and taking on foreign nationalities in "comparatively civilized states" such as the United States of America. His fear, therefore, was that in forty or fifty years, the societies of Chinese sojourners could completely disappear. The "sojourning Chinese" (Zhongguo qiaomin 中國僑民) would then not even remain Chinese in name. Tang repeatedly described the Chinese communities in Hong Kong and Taiwan and those in other parts of the world henceforth as "societies of Chinese sojourners" and thus dispensed with the terms "Chinese youth" and "society of Hua people," which would indicate much closer cultural ties with China. ${ }^{31}$ In this way, he made it clear that the progressive assimilation of Chinese communities into immigrant societies constituted a threat to the survival of "Chinese" communities outside the Mainland, not only in terms of sociological evidence, but also from a normative perspective.

According to Tang, the threat to Chinese communities was not in the first instance due to any physical danger facing their members. It was rather the self-conception of the emigrants as belonging to the Chinese nation that was in danger, and even more so since 1949: On the one hand, emigration prompted the question of the desirability of the individual's continuing identification with the nation, particularly in a colonial situation where the issue involved the choice between assimilation and anti-colonial opposition. On the other

terms "Zhongguoren" as well as "Huaren" appear to denote ethnic and/or cultural links to "China."

29 The term "Huaqiao" 華僑 dates back to the late 19th century and implies migration outside China. From 1910 until the regulation of its official use in the People's Republic, the term "Huaqiao" suggested belonging to the Chinese nation. Pan, The Encyclopedia of the Chinese Overseas, p. 16.

30 Tang, Shuo Zhonghua minzu zhi hua guo piaoling, p. 5.

31 Ibid., pp. 1-3, 39 . 
hand, emigrants had to weigh the question of how the Chinese nation should be defined and whether there could be to some extent an alternative "China" outside the communist Mainland and beyond a Taiwan ruled by the GMD. In Tang's opinion, the survival of China as a cultural nation was unquestionably in acute danger. He depicted this danger in 1961 by using the image of a large tree for the Chinese nation: The tree is threatened with extinction; its flowers and fruits are falling off and decaying, and some are gradually carried off by the wind. Only certain seeds continue to survive in the foreign soil of "other men's gardens," in shadowy, moist ground, and in the corners where they benefit from the muddy soil. ${ }^{32}$ As the metaphor implies, the Chinese nation may no longer be able to preserve its territory, history and culture, and, along with this, its morals and ethics, traditions and customs, and language and script. ${ }^{33}$

Tang's metaphor underwent an optimistic change in Tu Wei-ming, whose edited volume on "cultural China" is entitled The Living Tree. ${ }^{34}$ The contrasting metaphors may well be taken as indicators of a fundamental shift from an exilic to a post-exilic perspective. Tu Wei-ming retraces, from a post-exilic perspective, the current situation of Chinese sojourners to its voluntary nature:

Increasingly, overseas Chinese (huaqiao) have chosen to be Chinese (huaren) in their adopted countries. As emigrants, they have voluntarily severed their political ties with their mother country and, as immigrants, they have deliberately opted to settle down in the new land. ${ }^{35}$

Tu adds an observation that stands in stark contrast with Tang Junyi's worries about the dissolution of a common orientation toward China's cultural traditions among intellectuals in exile and overseas communities: "The term 'cultural China,' coined in the last decade or so ... is itself an indication of the emergence of a 'common awareness' among Chinese intellectuals throughout the world." ${ }^{36}$ Unlike Tu, Tang, in the 1950s and 196os, was concerned with the allegedly imminent decay of China's national culture. He felt that this might hinder the (cultural) "merging" and "absorption" within the nation, but also undermine the individual members' "intellectual determination" to protect

$32 \quad$ Ibid., p. 2.

33 Ibid., p. 22.

34 The contributions by Tu follow Tang's use of the term "cultural nation:" Tu, "Preface to the Stanford Edition," p. viii; Tu, "Cultural China: The Periphery as the Center," pp. 25-26.

35 Tu, "Preface to the Stanford Edition," pp. ix-X.

36 Tu, "Cultural China: The Periphery as the Center," p. 25. 
the nation and its culture. In assessing the current situation, Tang found that this determination had diminished among the diasporic communities of Chinese, which was equivalent to the "beginning of the complete collapse of the national spirit" and the imminent "great tragedy of the nation." Yet, Tang explicitly maintained that this was not a case of a "moral problem." The emigrants had no moral obligation toward the nation and its culture, and the exilic individual's interpretation of nation and culture was not to be morally judged. ${ }^{37}$

Therefore, instead of moralizing, Tang addressed the threatening consequences of converging exilic and colonial experiences. This convergence was a symptom of the continuing demise of the Chinese cultural nation. In Hong Kong and even in Taiwan, Tang saw signs of a (self-)colonialization of the "social and cultural consciousness." He found evidence of the colonialized servant's consciousness in the fact that interest in the Chinese heritage in the fields of science, education, and the arts was dwindling. In these fields the Chinese no longer set their "own standards," and consequently even "the standards for Chinese scholarship have fallen into the hands of outsiders." Tellingly, the exhibits from the Palace Museum in Taiwan were only appreciated by the Chinese when they were on loan to an exhibition, after having first aroused interest in the United States. ${ }^{38}$ No less worrying for Tang was the declining use of Chinese languages (Zhongguo yuwen 中國語文), which were no longer spoken even in the "homes of many high-ranking Chinese intellectuals in America and Europe." He critically observed that at a meeting in Hong Kong on the founding of the Chinese University of Hong Kong the majority of people did not have any qualms about speaking in English. For Tang, this was a new development. He pointed out that during the Republican period even the representatives of the so-called New Culture movement, who were critical of Chinese tradition, still used the Chinese language. ${ }^{39} \mathrm{He}$ also deplored that, in the meantime, it had become commonplace that Chinese academics study abroad in order to gain recognition from their compatriots. An unfortunate consequence of this was that those like the graduates of the New Asia College

37 On "intellectual determination" see Tang, Shuo Zhonghua minzu zhi hua guo piaoling, p. 5; on the "collapse of the national spirit" see ibid., p. 37; on the "tragedy of the nation" see ibid., p. 23; on the "moral problem" see ibid., p. 2.

38 Ibid., pp. 33-38. Tang did not elucidate any further here the link between the colonialized consciousness and Hegel's famous master and servant dialectic.

Ibid., pp. 4-5. 
in Hong Kong, who had not studied abroad, became disadvantaged in their careers and socially marginalized. ${ }^{40}$

\section{Intellectual Ethos and Messianic Vision}

As an intellectual and social critic in exile, Tang did not engage in practical politics. There were no political parties that had developed within Confucian exile circles, nor had a Confucian social movement emerged as such. Still, the politically active Zhang Junmai did speak of a Confucian "movement" in 1962 and he identified the periodical Rensheng 人生, founded in 1951 in Hong Kong, as its mouthpiece. Early references to a "new Confucianism" in the post-war period can indeed be traced back to articles published in Rensheng in 1963 . In addition, Zhang described the New Asia College as a "center for the reappraisal and revival of Confucianism." He additionally pointed to the existence of a programmatic platform, whose written testimony was the manifesto A Declaration to the World for Chinese Culture from $1958 .^{41}$ In support of the assumption that there was a "new" Confucian movement at that time, some scholars have also pointed to certain related developments prior to $1949 \mathrm{such}$ as the establishment of academies and publications from 1939 onwards. ${ }^{42}$ As early as 1941, the philosopher He Lin 賀麟 (1902-1992) had made mention of a "new Confucian movement" in reference to a "modern culture" in China. The movement's impact as a main strand within politics, society, and culture was said to be only a matter of time. ${ }^{43}$

Yet there is sufficient reason to doubt whether there was really a "movement" in the 1950s and 196os. For example, the locations of the persons mentioned above would seem to contradict the idea of a concentrated Confucian engagement with political or social forces: Zhang Junmai mostly lived in the

40 Ibid., pp. 36-37; cf. also ibid. Tang, Zhonghua renwen yu dangjin shijie bubian, Vol. 9, pp. 491-492. Yet it seemed that not all was lost: Tang also recognized signs for China's increasing cultural significance in the world, such as the presence of Chinese culture and language as subjects of study at foreign universities. Tang, Shuo Zhonghua minzu zhi hua guo piaoling, p. 44.

41 Chang (Zhang Junmai), The Development of Neo-Confucian Thought, Vol. 2, p. 7. On the Rensheng-articles from 1963; see Makeham, "The Retrospective Creation of New Confucianism," pp. 26-27.

42 For example, Fang, Xiandai xin rujia xue an, Vol. 1, 17-19, 22-24; Bresciani, Reinventing Confucianism: The New Confucian Movement, pp. 18-21.

He, "Rujjia sixiang de xin kaizhan," pp. 611-612. 
United States after 1949; Tang Junyi and Qian Mu had lived in Hong Kong since 1949; Mou Zongsan stayed in Taiwan until 196o, before moving to Hong Kong; and $\mathrm{Xu}$ Fuguan also moved to Hong Kong nine years later. By that time, the journal Rensheng had already ceased publication. ${ }^{44}$ As regards the New Asia College, which Zhang had identified as the institutional "center" of the movement, Grace Ai-Ling Chou concludes in a recent study on its formation and development that "New Asia's attempt to construct a cultural education that would be Confucian in content, structure, and style was far from straightforward." Chou further explains that the founders of the college allowed for a conceptual breadth in their understanding of culture that "... although potent in its very vagueness and inclusiveness, would lead to increasing uncertainty over the exact scope and nature of the Chinese culture they aimed to preserve."45

There were, moreover, significant political differences among these Confucian intellectuals. Even though Tang, Zhang, Xu, Mou, and Qian all held anti-communist convictions, they expressed divergent criticisms of world communism and Chinese communism. Their political outlook was even more inconsistent when considering their attitude toward the nationalist government of the GMD on Taiwan. For example, Qian Mu, who was not among the signatories of the above-mentioned manifesto, had much fewer reservations about the rule of the GMD in post-war Taiwan than Tang or Zhang Junmai did during the 1950s. The political differences and ambiguities do not end here, however. There was also room for disagreement in the field of political theory. Tang and Xu Fuguan, for instance, openly and intensely discussed their concepts of democracy and the relationship between science and politics at the beginning of the $1950{ }^{4} .^{46}$ As a matter of fact, at no point in Tang's lifetime did modern Confucianism have a common political program. It is, therefore, not surprising that Tang indicated in private correspondence on the manifesto that the rumors about an alleged desire to come together as a political party were to be dismissed. ${ }^{47}$ What is more, the manifesto of 1958 was not conceived

44 Rensheng appeared until 1968; another important periodical, Minzhu Pinglun, was founded in 1949 in Hong Kong and existed until 1966.

45 Chou, Confucianism, Colonialism, and the Cold War: Chinese Cultural Education at Hong Kong's New Asia College, 1949-76, p. 3.

46 Mou Zongsan declared himself in favor of Tang: Lee, Xu Fuguan and New Confucianism in Taiwan (1949-1969): A Cultural History of the Exile Generation, pp. 186-188, 192-204. Differences also arose between Qian Mu and Xu Fuguan towards the end of the 1950s and at the start of the 196os, ibid., pp. 208-218.

Tang, Shujian, p. 116 (letter of November 28, 1957 to Mou Zongsan and Xu Fuguan). 
as a partisan platform, and Tang himself in fact explicitly stated his disinterest in political activism. ${ }^{48}$ His position is thus markedly different from that of Zhang Junmai, who, 22 years his senior, had already founded a political party at the beginning of the 1930s, and, at the start of the 1950s, tried in vain during a short but intensive period to organize a political "Third Force." Tang, by the way, never joined Zhang's "Third Force" activities, even though his own political vision of a future unified and democratic China was basically in line with Zhang's outlook. 49

What was actually achieved in the 1950s and 1960s within the Confucian exile circles was a rather loose intellectual, academic, and cultural-political collaboration-such as the one between Tang and Qian when they worked together in founding the New Asia College. None of these intellectuals, however, was engaged in political or social activism. It is, therefore, no coincidence that the programmatic term "new Confucianism" only rarely appears in the exilic writings of Confucian intellectuals in the 1950s and 1960s, and, when it does, that it varies greatly in meaning. Even Zhang Junmai did not use this term in the first instance to describe contemporary Confucianism of the 2oth century, but rather Confucian currents of the late imperial period. ${ }^{50}$

Although Tang was not part of a movement and abstained from practical politics, his life in Hong Kong was also not entirely one of quiet scholarly harmony. For despite his experience of exilic hardship, he never fully retreated into the academic world. In fact, besides his work in academic philosophy, a central component of his intellectual activities consisted of writing texts and delivering lectures that addressed a general audience. He had already been active in this respect at the very outset of his life in exile and published a remarkable number of articles in a variety of journals and magazines targeted at a well-educated readership. ${ }^{51}$ Furthermore, from $195^{\circ}$ onwards, Tang organized a series of public lectures and seminars with various speakers and hosted over 100 events, mostly for small groups of 20 to 30 attendees. In 1962, together with the philosopher Mou Zongsan and others, he founded the Study Society for Eastern Humanism (Dongfang Renwen Xuehui 東方人文學會) in Hong Kong, which assembled about 70 members worldwide. In addition, he

48 For instance in an article that was published in 1955 in the journal Ziyou Ren 自由人: Tang, Zhonghua renwen yu dangjin shijie bubian, Vol. 9, p. 421.

49 Xue, Minzhu xianzheng yu minzuzhuyi de bianzheng fazhan-Zhang Junmai sixiang yanjiu, pp. 52-53.

50 Cf. his essay in Rensheng, No. 297 (March 1963) entitled "Xin rujia sixiang shi xie wan yihou 新儒家思想史寫完以後."

$5^{1} \quad$ See Feng, Tang Junyi xiansheng jinian ji, pp. 7-28. 
was continuously involved in a diverse range of academic societies. ${ }^{52}$ The New Asia College's public lecture series which was conducted from 1950 to 1955 is worth noting in this regard. It comprised 122 lectures on a wide range of topics, including a "Comparison between Chinese and Western Medical Theory," "Buddhism and Christianity," "The Spirit of Kantian Philosophy," "Islamic Scholarship in Medieval Times," "The American Presidential Election System," and "The Position of Science in a Free Education." Tang participated himself in this series, delivering altogether sixteen lectures..$^{53}$

The above-mentioned intellectual activities, while quite diverse, shed some light on Tang's self-image as an intellectual in exile. His activities were borne of the conviction that intellectual engagement-as social critic, writer, lecturer and educator - could contribute to an enhancement of China's "national spirit." This belief was probably motivated by both foreign and Chinese influences. Inspiration from abroad ranged from Babbitt's New Humanism to the German philosopher Rudolf Eucken, who had gained enormous popularity on the eve of the First World War by publishing texts like Der Sinn und Wert des Lebens (1908) or Zur Sammlung der Geister (Leipzig 1913). ${ }^{54}$ Important Chinese stimuli, on the other hand, included models for exerting intellectual-spiritual influence, among them the communities of followers of Confucian "masters" (beginning with Confucius himself), and the Confucian academies in late imperial China. The founding of academies in the Confucian circles of the Republican period continued to point in this direction, as did the establishment of the New Asia College in Hong Kong. ${ }^{55}$

$5^{2} \quad$ Fang, Xiandai xin rujia xue an, Vol. 1, pp. 23-24.

53 Chou, Confucianism, Colonialism, and the Cold War: Chinese Cultural Education at Hong Kong's New Asia College, 1949-76, pp. 39-41.

54 On Eucken, see Lübbe, Politische Philosophie in Deutschland. Studien zu ihrer Geschichte, p. 179. Eucken was awarded the Nobel Prize in 1908 and became an internationally renowned public speaker. As Lübbe expounds, Eucken's brand of idealism was marked by its "Weltanschauungscharakter" (character as a world view) and primarily aimed to reach a non-academic public. Its focus was clearly on the "geistige Tat" (intellectual-spiritual act). Accordingly, the aim of the so-called Eucken-Bund, a sectarian association founded in 1922, was to contribute to "the moral strength of German life." See ibid. Eucken's thought became popular in China in the 1920 s and 1930s; see Meissner, China zwischen nationalem 'Sonderweg' und universaler Modernisierung. Zur Rezeption westlichen Denkens in China, pp. 82-110.

55 As Chou observes: "The New Asia founders believed the traditional Chinese academy, the shuyuan (书院) of Song and Ming times, to be the ideal institutional form for the fostering of 'well-rounded talent' since it nurtured students not only academically but also morally through its encouragement of close student-teacher relationships. In such 
But Tang was neither nostalgic about the pre-modern idea of exemplary Confucian figures, nor did he expect that the educational ideals exemplified by Confucian academies in late imperial China could be implemented in contemporary Hong Kong. He thus summed up the impact of New Asia College in skeptical, rather pessimistic manner in 1960:

This academy was intended to carry on the tradition of Neo-Confucianism in the Song and Ming Dynasties, but it is still far from reaching that goal. Song and Ming academies had no concern for the career of their graduates. The primary requirement for disciples of Zhu Xi or Wang Yangming was to make up their mind to "carry on the teachings of past sages that would otherwise be lost and usher in a time of peace to last forever." This is beyond any career. (...) Such an ideal is of course somewhat too high for today's students, and no teacher dares to compare himself to Zhu Xi or Wang Yangming. In addition, our perception of the times cannot be the same as theirs in the Song and Ming Dynasties ... (...) In the past, if a scholar would not take the imperial civil service exam, he could study in the countryside while making a living as a farmer, which is impossible today. That is a major problem facing us. We are caught between the past and the present, the ideal and the reality, what is beyond career and the need to face it. ${ }^{56}$

Overall, the intellectual's ethic of responsibility, upheld by Confucian emigrants after 1949, differed sharply from the traditional ethos of the Chinese literati. The latter demanded that an educated person promote the commonweal and encouraged him to take office in the imperial administration. The traditional ethos did not vanish altogether, however, with the founding of the republic in 1912. Roger T. Ames has pointedly observed that "[m]any Chinese philosophers of our generation continue the tradition wherein scholar-officials are institutionalized intellectuals who have the practical responsibility to forge a 'way' for the daily workings of government and society."57 But in the colonial

relationships, teachers were to serve not merely as dispensers of information but as personal mentors and moral guides..." Chou, Confucianism, Colonialism, and the Cold War: Chinese Cultural Education at Hong Kong's New Asia College, 1949-76, p. 23.

56 See Tang's article in New Asia Life Biweekly, Vol. 1, No. 17, pp. 1-2 (1960); quoted from: Hong, "The Characteristics and Prospect of the Confucian Academy: A Commentary on Jiang Qing's Ideas on the Confucian Academy," p. 190.

Ames, "New Confucianism: A Native Response to Western Philosophy," p. 79. 
environment of Hong Kong, the ethos of the scholar-official inevitably faded away and became little more than a romantic social idea.

Since opportunities for political and social engagement were no longer the same as on the Mainland prior to 1949, let alone in imperial times, intellectuals in exile inevitably found themselves faced with the fundamental question of their self-image. It seems that the experience of exile strengthened Tang's personal determination to advocate for a reconstruction of Chinese "national culture" and humanism. At the same time, he grew increasingly critical of the democratic achievements of the various Chinese regimes in the 2oth century. At the same time, intellectual life on the exilic periphery not only meant that Tang was physically detached from the Chinese governments on both sides of the Taiwan Strait, but it also provided him with a unique opportunity: He was now able to adopt the role of an intellectual unburdened by the traditional ethos of scholar-officials. Since he was no longer subject to status-based obligation to become a civil servant or an advisor to those in power, he was free to become an unrestrained social critic.

The socialist state of the PRC and the GMD state in Taiwan did not allow for a public sphere in which social critics, safeguarded by constitutional rights, could be active. While in exile, Tang thus addressed the democratic Chinese state and its public with futural concepts, i.e. normative anticipations. In the same vein, he conceived of a type of cosmopolitan intellectual who so far had been largely absent in China. The ethos of this intellectual was informed by the awareness that in order to shoulder social responsibility for the moral-humanistic betterment of humankind, it was necessary to act from the peripheral position of a critical observer in exile. Equally important, the ethos contained elements of self-blame insofar as the intellectual elite felt obliged to take responsibility for China's belated efforts to modernize, the failings of Chinese democracy, and the "loss" of the Mainland in 1949. It is thus no surprise that Tang, in pondering the reasons for the failures of the republic after 1912, assigned considerable blame to the role played by Chinese intellectuals (see Chap. 9).

The language of the Confucian intellectual in exile was "philosophical," albeit in a more popular than strictly academic sense. Tang was well aware of the difference between academic and popular philosophy, attributing to the latter the task of addressing broader social issues. ${ }^{58}$ Tang moreover aspired to

58 See, for example, his foreword (from 1974) to the reprint of his book Renwen jingshen zhi chongjian (p. 19). In the foreword to the first edition of this book, Tang already states that the book does not intend to address specialists, but people engaged in social and cultural 
the conception of a unity of philosophy and a philosophical way of life, which he inscribed into his modern Confucian project. The aim to instill his philosophy with practical import entailed the risk of undermining critical reflection on modern society by relegating philosophy to a resource (or "wisdom") for an unburdened individual conduct of life. Indeed, the continuous struggle to negotiate between these two poles without however retreating to either of one of them characterizes Tang's philosophical endeavor.

Tang's self-image as intellectual and philosopher is even more ambivalent than it might initially appear. In looking back on his personal and intellectual development, he professed that early in his life he had felt responsible for setting out on a mission to save humanity. According to Tang Duanzheng's Chronicle of the Life and Work of Tang Junyi, Tang Junyi believed at age 26 or 27 that he had grasped - in a moment of sudden enlightenment - the fundamental truth of the universe and of human life, and was convinced that all humanity should do so as well. This epiphany allegedly occurred in 1935 at Xuanwu 玄武 Lake in Nanjing and appears to mark a turning point in Tang's intellectual life. ${ }^{59}$ It is difficult to know the degree to which this messianic selfawareness actually has come to bear in Tang's philosophical writings. ${ }^{60} \mathrm{He}$ generally divided his roles between the intellectual who dealt with the historical world and the messianic visionary who embraced the ultimate realm of liang zhi. It seems likely nonetheless that he was deeply convinced throughout his life that he should strive to guide the minds of his fellow men to the highest realm. Kevin Cheng harshly comments: "When he [Tang] was 27 (1935) he

matters, including activists, educators, journalists, editors, those active in the field of religions, and the "youth" (ibid., p. 22).

Tang, Nianpu, p. 33. Tang also recounted how before the age of 30 , he often felt that his "mind" (xinling 心靈) was located at the periphery of the world, adding that he frequently practiced meditation (quiet-sitting; jingzuo 靜坐) and experienced what "Western mysticism” would call “enlightenment" (zhengwu 證悟); see Tang, Shengming cunzaiyu xinling jingjie, Vol. 24, p. 476. There is unfortunately still no biography to date of Tang that psychologically interprets this account or the letters to his wife Xie Tingguang from November 1941, which indicate that he experienced a severe personal crisis at that time; see Tang, Nianpu, pp. 48-51.

6o At times, Tang even struck a more playful note in trying to carry out his mission: For example, he wrote a philosophical children's story entitled "The Journey of Human Life" (Rensheng zhi lüxing 人生之旅行, first published by Zhonghua Shuju in 1939/40), and the "Songs in Praise of Mind, Principle and the Way" (Xin Li Dao Song 心理道頌); see Tang, Rensheng zhi tiyan, pp. 237-298 (Rensheng zhi Lüxing), pp. 299-337 (Xin Li Dao Song; 1941). 
arrogantly considered himself as having mastered the foundational truths of the universe and human life."61 Perhaps this was indeed just a matter of arrogance. Just the same, Tang found himself in the company of renowned Chinese and Western thinkers who were equally unswerving in their testimony and sense of mission, including many of his neo-Confucian predecessors like Zhu Xi and Wang Yangming, prominent contemporary Confucians like Kang Youwei and Liang Shuming, but also Western masterminds like Hegel, Fichte, Comte, and Eucken.

Tang's messianic self-awareness also resonates from his own account of a crucial childhood experience in which he realized the end of human times. It is not the biographical credibility of this narrative that is of interest here, but rather the much more telling fact that Tang portrayed himself in his mid-forties as a thinker who had always been driven by the notion of an end of human time. Even though he did not envisage an eschatological end of humanity, his reflection on an end time nonetheless bears the imprint of a personal awakening to transcendence:

In retrospect, the root of my antipathy towards any thoughts that regard man as a natural animal, which is the source of my philosophical thinking, can be traced back to an experience when I was only six or seven years old. One day my father told me the scientific prediction that the light and heat of the sun would [one day] vanish. The earth would then reach its final day. By the time of the earth's final day, there would be only one man with his dog. I remember that this story roused my boundless interest. Several days later, the earth of our courtyard cracked and warped in the sun after a rain. At that time, I thought that the earth might split and collapse. By now, the situation in the courtyard occurred already

61 Cheng, Karl Barth and Tang Junyi on the Nature of Ethics and the Realization of Moral Life: A Comparative Study, p. 483. Tang's strong sense of mission is also evident in his own description of the state of mind that he achieved when writing in an inspired manner: "This self which resides in tranquility seems like a spirit which is totally alone and has nothing to cling onto from the above and from below. This spirit, on the one hand, opens up the door of Heaven so that the horizon of principles descends upon me; and on the other hand surveys the world below. To myself and to those who exist in reality, sometimes I am sympathetic and compassionate, and sometimes I am pious and celebrating. Therefore when I am writing I often feel a tender passion pulsating within me, and I am so touched that I cannot restrain myself from tears." (Tang in Rensheng zhi tiyan; quoted from: Cheng, Karl Barth and Tang Junyi on the Nature of Ethics and the Realization of Moral Life: A Comparative Study, pp. 325-326). 
forty years ago. I still remember it very vividly. This is, I believe, the source of my philosophical thinking and all my opinions about human nature. Why do people think of the destruction of the world? Included in this [contemplation] is the mystery and dignity of human nature and the difference between man and animals. (...) How can I imagine the havoc of the world while bearing this very existence in my mind? Later on, I reached the firm understanding that man is [a form of] existence which entails the transcending of the material world. ${ }^{62}$

Insofar as Tang's own account points to the theological layers of his philosophy, it provides more insight than those enthusiastic judgments that portray him as a heroic guardian of China's humanistic traditions in a hostile modern environment. The most influential words of such praise came from Mou Zongsan who, in a commemorative text after Tang's death, called him a "giant in 'the universe of cultural consciousness." Mou further compared Tang's intellectual standing to that of Newton, Einstein, Plato and Kant as well as Huang Zongxi 黃宗羲 (1610-1695), Gu Yanwu 顧炎武 (1613-1682), and Wang Fuzhi 王夫之 (1619-1692) in their respective fields and times. ${ }^{63}$ The problem with this facile judgment is not only its enthusiasm, but also the fact that it labels Tang with the cliché of a defender of Chinese spiritual culture. This cliché might, moreover, lead to the insinuation that Tang, as such a defender, belongs to the ranks of philosophers of life like Rudolf Eucken, who had diagnosed Germany as being in the midst of a spiritual crisis of unprecedented dimensions. Eucken had warned that the deluge of "reflection, criticism and negation" would put the country in danger of betraying its intellectual and spiritual imprint that had been given to it by "men like Luther, Kant, Goethe, Beethoven," and the philosophers of German idealism. ${ }^{64}$ In contrast, Tang Junyi was not primarily concerned with threats to the intellectual-spiritual life or the Seelenleben of the nation as such; his focus was much more on the decay of intellectual and cultural preconditions for the individual's ability to exert "reflection, criticism and negation" in modern society.

62 Tang, Renwen jingshen zhi chongjian, p. 566 (this passage is taken from Tang's account "Wo duiyu zhexue yu zongjiao zhe jueze"); I follow here the translation of Yuk Wong (see Tang, "My Option Between Philosophy and Religion," pp. 414-415), albeit with some alterations and amendments.

63 Mou, “Aidao Tang Junyi xiansheng 哀悼唐君毅先生 (Feb. 12, 1978),” pp. 272-273.

64 For an analysis of Eucken's diagnosis (as elaborated e.g. in Der Sinn und Wert des Lebens), see Lübbe, Politische Philosophie in Deutschland. Studien zu ihrer Geschichte, pp. 180-182. 


\section{Nation and Culture}

Tang Junyi proposed to the various communities of Chinese emigrants that they adopt a self-image that reflected the common experience of exile as one of suffering due to the looming demise of China's national culture. Just the same, many emigrants were apparently no longer linked as a community by the shared experiences of cultural vulnerability. In the eyes of Tang, this transformation had far-reaching consequences, because isolated individuals would not be able to cope with the experience of exile, which is only possible through participation in a cultural community. The idea of such a community was, however, neither embodied in contemporary communities of emigrants, nor in the nationalist definition of China established in Taiwan by the GMD regime. The desirable community envisaged by Tang would consist of members who agree that the binding qualities of the nation are humanistic and cultural in nature. They would furthermore assume that the nation consists of an ongoing, open process of interpretation and identification of national culture by its members. Any dogmatic definition of the national culture would undermine the continuation of the national culture itself.

Even if Tang could not avail himself of a phrase in Chinese for "cultural nation," he interpreted the Chinese nation to a certain extent in the classical manner as a cultural nation. Cultural-nation theorists assume, first of all, that the nation is a form of community worth striving for, mostly because it allows its members to autonomously achieve political unity. As the term suggests, the nation acquires its cohesive power through its "national culture," which functions as a source of communal values, including equality, justice, freedom, autonomy and solidarity, and common daily life practices. ${ }^{65}$ It goes without saying that those who see themselves as members of the nation assume that historical reality befits the national culture as well as the nation itself. ${ }^{66}$ Tang, too, presented China's "national culture" as the central cohesive force for the

65 It was Max Weber who identified a feeling of solidarity as the crucial criterion of any claim to establish a nation: "In the sense of those using the term ["nation"— $\mathrm{TF}$ ] at a given time, the concept undoubtedly means, above all, that it is proper to expect from certain groups a specific sentiment of solidarity in the face of other groups." Weber, Economy and Society: An Outline of Interpretive Sociology, Vol. 1, p. 922.

66 Lepsius, "Nation und Nationalismus in Deutschland," pp. 193-194, 197. As is well-known, the term "imagined community" calls to account the fact that the nation as opposed to the nation-state has at its disposal neither fixed international borders, nor clearly identifiable constitutional institutions. See, for example: Koselleck, "Volk, Nation, Nationalismus, Masse," pp. 148-149, 388; Anderson, Imagined Communities: Reflections on the Origin and Spread of Nationalism, pp. 5-7; Geulen, “Die Metamorphose der Identität," p. 348. 
Chinese nation and, at the same time, as the point of reference for endowing individuals with orientation and shared interpretations of the historical world. In emphasizing the continuity or longue durée of the nation, the concept of the Chinese cultural nation as developed in modern Confucianism is also consistent with classical theories of the cultural nation. Accordingly, the national culture is imagined to be a time spanning horizon of shared values, ideas, norms and practices, which extends from the past to the present and into the future. While conceding that contingency plays a part in the history of the nation, Tang and the co-authors of the manifesto of 1958 were convinced that the longue durée of the nation was mainly the upshot of ideational, intentional factors, among which Chinese philosophy and religion were particularly influential. ${ }^{67}$

In his narrative of the historical formation of China's national culture, Tang highlighted the topics of unity and continuity. He claimed that Chinese culture evolved out of a "single root" and took the form of a single "cultural system" early on, whereas Western cultures evolved in different currents. ${ }^{68}$ Even though he conceded that there were distinct "cultural regions" in Chinese antiquity, and thus different cultural "trunks," he believed that a consistent current of cultural transmission had already emerged as early as the age of the Three Dynasties (Xia, Shang and Zhou; third millenium BCE to 221 BCE). He further suggested that in the imperial age of the Qin, Han, Tang, Song, Yuan, Ming and Qing Dynasties, a "continuous course" of "transmitting the way" in culture, scholarship and thought had persisted despite changing periods of territorial and political “separation" ( $f e n$ 分) and “unification" (he 合). ${ }^{69}$

67 With regard to philosophy and religion, the authors of the manifesto placed particular emphasis on the respective "notions of human life" in this context: Zhang, Zhongguo wenhua yu shijie, p. 27.

68 Zhang, Zhongguo wenhua yu shijie, p. 13. According to Tang, there were three dominant currents in Western culture: Greek (in philosophy), Hebrew (in religion), and Roman (in law). On this basis, "relatively autonomous domains in culture and scholarship" evolved, as Tang claimed; see ibid., p. 14. In a similar manner, Tang referred to Whitehead's distinction of Western notions of transcendence in the form of ideas of fate in Greek tragedies, the Roman notion of law, and the Christian notion of creation; see Tang, Zhongguo wenhua zhi jingshen jiazhi, pp. 75-76.

69 Zhang, Zhongguo wenhua yu shijie, p. 13. The use of fen and he is allusive to the quasimetaphysical elevation of the empire as narrated in the The Romance of the Three Kingdoms. In the same context, Tang was also using the common allegory of the "great river" to refer to the course of China's national culture and its "humanistic spirit" which was said to continuously absorb both religion and politics in spite of dynastic change; see Tang, Renwen jingshen zhi chongjian, p. 414. 
Tang's depiction of the Chinese nation and culture is clearly tautological. First, he treated the national culture as a historical fact and described its allegedly typical features, such as an inherent consistency and continuity. He then assumed that these features of national culture were expressed in the nation, i.e. in the "national" way of life. This entailed humanistic traditions, spiritual values, and popular, as well as elitist culture. The national culture, it would thus seem, is manifest in the nation, which, in view of the tautology, is unquestionably an objectively existing entity. Since the nation exists, therefore, so must its essential resource, the national culture. The tautology does not end here, however, for it also includes the conflation of a factual and normative proposition that basically amounts to the following statement: Because there is such a thing as the Chinese nation objectively speaking, the national culture should be made to persist. This tautological approach, taken together with its schematic patterns of cultural essence, chauvinistic portrayal of non-Chinese cultures ${ }^{70}$ and claim of the longue durée of the nation and its culture, is reminiscent of the so-called "metaphysics of Germanness" ("Deutschtumsmetaphysik") which was current in Germany in the early 2oth century. Much like the metaphysics of Germanness, the manifesto of 1958 claimed global significance for national culture and derived a strong sense of a historical mission from that fact. One of the eminent philosophers of the "German spirit" was indeed the same Rudolf Eucken whose writings Zhang Junmai and others had intensively studied since $1920 .^{71}$

It was on this basis that Tang's modern Confucianism strongly emphasized the importance of Chinese national culture and the Chinese nation. In the metaphor of the uprooted tree, the final collapse of China is, significantly, tantamount to the collapse of the nation, which, in turn, results from the dissolution of its cultural cohesive forces, and not simply from the seizure of power on the Chinese Mainland by communist armed forces in 1949. Tang thus did

70 See, for example, the judgment about Indian culture as lacking self-consciousness: Zhang, Zhongguo wenhua yu shijie, p. 26. In a similar manner, there are assertions that in antiquity the "value" of "Chinese" culture was higher than the value of "barbarian" cultures; ibid., p. 30.

71 On Eucken's metaphysics of Germanness, see Lübbe, Politische Philosophie in Deutschland. Studien zu ihrer Geschichte, pp. 187-188. It is also noteworthy that beginning in the early 1950s, in the context of the formation of modernization theory, there was a strong tendency in American anthropology, social sciences and historical research to posit essentialist concepts of more or less unchangeable elements of American culture and national character. Notions of an American exceptionalism and book titles like The American Mind were not uncommon; see Knöbl, Spielräume der Modernisierung. Das Ende der Eindeutigkeit, pp. ${ }^{135^{-138}}$. 
not accord key significance to the territorial boundaries of the nation. Indeed, if territorial integrity were solely responsible for the nation's survival in the form of a nation-state, Tang would no longer have needed to trouble himself with pondering the future course of the Chinese nation after 1949. When he still referred to the Chinese nation long after the communist takeover, he was evidently aware that its territory no longer constituted a unified nation-state. The cultural nation, in other words, no longer had any state territory to lose. It was, however, in danger of losing its national culture. Herein lay its true vulnerability:

On the other hand, considering it objectively, Chinese culture can persist in the world, whereas the Chinese nation withers away, just like the Greek culture persists, whereas the Greek nation withered away. There is no guarantee for a necessary integration of any nation and culture. However, this fact itself is again causing me pain. (...) Neither have we resigned to the Chinese nation's withering away or to the persistence of Chinese culture solely in the mind of Sinologists. (...) Culture might surpass the nation and have an influence on other nations, whereas the nation cannot part from its original culture. ${ }^{72}$

The exilic project of Tang's modern Confucianism, therefore, did not need to join with the political and military struggle of the GMD regime to recover the territory of the Chinese nation-state on the Mainland. Instead, it was sufficient to react to the concerns about the continuity of China's "national culture." This was not about defending outer, territorial borders of the nation-state, but a matter of ensuring the inner cohesion of the nation by renewing the appeal of national culture among Chinese communities worldwide. Toward this end, Tang introduced, concomitantly with other representatives of modern Confucianism, the notion of a "main current" (zhu liu 主流) within China's national culture. This current is said to consist of the so-called "study of mind and [human] nature," which allegedly constitutes the "core" (hexin 核心) or the

72 Tang, Shuo Zhonghua minzu zhi hua guo piaoling, p. 53. In this context, a statement made by Michael Walzer on the South African poet and exiled intellectual Breyten Breytenbach sounds familiar: "If he [Breytenbach—T.F.] is marginal to the world that apartheid has made, he nonetheless declares himself to be in the mainstream of his own history and his national culture." Walzer, The Company of Critics, p. 218. 
"essence" (benzhi 本質) of Chinese culture and scholarship. ${ }^{73}$ This essence, in fact, is said to be the spiritual lifeline of China's national culture:

As mentioned above, in conducting research about Chinese history, culture and scholarship, we have to consider these as manifestations of the objective spiritual life of the Chinese nation. But where is the core of this spiritual life? We can say that it is amidst the thought or philosophy of the Chinese. This is not to say that Chinese thought or philosophy would determine the culture and history of China. But it is to say that only by starting from Chinese thought or philosophy can one illuminate the spiritual life in Chinese culture and history. ${ }^{74}$

The reference to "thought or philosophy" might have been misleading because the "study of mind and [human] nature" was not to be mistaken for academic philosophy. According to Tang, the aim was not only to coin a scientific theory or to indulge in pure reflection on human practice. The "study of mind and [human] nature" was, after all, imbued with religious ideas, many of them about human nature, the position of man in cosmos, and the spiritual embodiment of transcendent agents (such as "Heaven," Buddha, gods) in the human being. Although these concerns are of course not exclusively found within Confucianism, the manifesto of 1958 strongly asserts that the "main current" attained its most comprehensive expression in the context of Confucian traditions and experienced its heyday during the Song and the Ming Dynasty. ${ }^{75}$

The meaning of "Confucian" is understood here in its very broad sense. Accordingly, the concept of Confucian traditions does not rely on references to a clearly defined canon of authoritative texts that would comprise the point of departure for a sought-after contemporary revival of Chinese culture. ${ }^{76}$ For all its essentialist aspects, this depiction of a main current is generally intended to

73 Zhang, Zhongguo wenhua yu shijie, pp. 8, 21. At times Tang also used the term "discourse on mind and [human] nature" (xin xing lun 心性論) instead of "study of mind and [human] nature;" see for example: Ibid., p. 389 .

74 Ibid., p. 12. In this context see also Tang's rejection of the assumption that the contents of national culture may be defined in an "objective," positivistic manner: Tang, Shuo Zhonghua minzu zhi hua guo piaoling, p. 8.

75 Zhang, Zhongguo wenhua yu shijie, p. 21.

76 On the identification of "Confucian thought" as a main intellectual current within China's national culture, see, for example, Tang, Renwen jingshen zhi chongjian [Hong Kong], p. 592; Tang, Zhongguo renwen jingshen zhi fazhan, p. 374, as well as Zhang, Zhongguo wenhua yu shijie, pp. 8, 11-12, 21. 
provide a basis of inclusion for non-Confucian thought. This is demonstrated by the way in which Tang presented the historical development of the main current, dating it back the period of the so-called Warring States (403-221 вСЕ). ${ }^{77} \mathrm{He}$ asserted here that one salient feature of the "study of mind and [human] nature" is the various notions of continuancy, which were coined in a broad range of references and over the course of millennia. They covered, for example, Daoist notions of longevity, religious practices such as the ancestor cults during the Zhou Dynasty, Confucian notions of the human mind's "permeating the mind of Heaven" (tong yu tian xin 通於天心), but certainly also the very idea of preserving the Chinese nation and its culture. ${ }^{78}$ That the "main current" is not thought of as exclusively Confucian is also evident from a reference to Buddhism, which is said to converge to some extent with the "study of mind and [human] nature." Yet as inclusive as it may seem, this approach still bears the imprint of a Confucianization of non-Confucian thought, as the discussion of Buddhism in the manifesto of $195^{8}$ clearly shows: The authors' interest in Buddhism is focused explicitly on its quasi-Confucian aspects, and the evaluation of Buddhism is accordingly based on this criterion. Buddhism is thus appraised for its convergence with the "study of mind and [human] nature," and Buddhist-inspired scholars of the late Qing-period like Kang Youwei, Zhang Taiyan's 張太炎 (Zhang Binglin 張炳麟, 1868-1936) and Tan Sitong 譚嗣同 (1865-1898) are lauded for their interest in the "study of mind and [human] nature." The manifesto is quick to add, however, that Buddhistinspired interpretations do not grasp the "study of the mind and [human] nature" in the same manner as the "Chinese Confucians" of the Song and the Ming-periods. ${ }^{79}$

Whenever the tradition of the "study of mind and [human] nature" was presented as crucial for understanding how the history and culture of the Chinese nation attained their remarkable consistency, the focus was on the Confucian humanistic belief in the human being's ability to "know human nature" (i.e. "its essence"; zhi qi xing 知其性), and thereby to "know Heaven"

77 Zhang, Zhongguo wenhua yu shijie, p. 27.

78 On Daoism (Tang refers to the Daodejing 道德經) and Confucianism (with references to the Yijing and Zhongyong 中庸): Ibid., pp. 27-29; on filial piety: Ibid., p. 29.

79 Ibid., pp. 21-22. The accentuation on Chinese Confucians indicates that the reference to the periods of the Song and the Ming has strong national-cultural and/or ethnic connotations and significantly excludes Confucian thought from the "non-Chinese" periods of the Yuan and the Qing. These connotations are also present in the Chinese term Song Ming lixue 宋明理學 which is often translated as “Neo-Confucianism." 
(zhi tian 知天) by “exerting his mind” (jin qi xin 盡其心). ${ }^{80}$ In Tang's interpretation, Confucian humanism elevates the human being to the position of the "soul" of this-worldly reality (the "ten thousand things") and accords an "absolute" value to individual personhood. While Confucian humanism is different from a belief in "objectively [present] gods," it still has a religious dimension which centers on the belief that the human mind may permeate "Heaven." The Confucian humanism that Tang had in mind was thus not at all antagonistic to religions; on the contrary, humanism was "complete" only insofar as it acknowledged the importance of religions. It is on the basis of this premise that Tang stressed the potential of Confucian humanism to accept and incorporate non-Confucian religions, while at the same time comparing this quasitranscendental outlook of Confucian humanistic religiosity with Western forms of idealistic philosophy. He consequently described Confucian humanism as an "idealistic humanism" or "humanistic idealism." ${ }^{81}$ To delineate the broad range of possible manifestations of Confucian humanism, Tang further referred to it as a "view of life," a "thought," an "attitude" and a "belief." Like most forms of Western humanism, Confucian humanism strongly emphasizes a comprehensive intellectual, moral and spiritual education of the individual. It also with humanism in Western traditions the reverence for "humanity and its culture" in general. Tang actually asserted that Confucian humanism attributes an even higher position to culture. ${ }^{82}$ Further similarities pertained to the emphasis on ethical relations and the focus on the historical dimension of the world. ${ }^{83}$ Equally consistent with common depictions of Western humanism was Tang's judgment that Confucian humanists were immune to the lures of dogmatism. When encountering "non-humanistic" or "anti-humanistic"

8o Cit. from Tang, Renwen jingshen zhi chongjian, p. 6o; see also Zhang, Zhongguo wenhua $y u$ shijie, pp. 23-24, 26. Tang refers here to Mencius viIA.1: "Mencius said, 'For a man to give full realization to his heart (jin qi xin) is for him to understand his own nature (zhi qixing), and a man who knows his own nature will know Heaven (zhi tian).'” This is D.C. Lau's translation: Lau, Mencius, p. 182.

81 Tang, Renwen jingshen zhi chongjian (Hongkong), pp. 592-597. On the above-mentioned notion of a "complete" humanism, see a passage in Tang's Zhongguo wenhua zhi jingshen jiazhi as quoted in He, "Tang Junyi lun rujia 'sanji' de zongjiao jiazhi," p. 68.

82 Tang elaborated in this context on the term "wen" in "renwen" and is aware of the fact that "wen" has certain layers of meaning that are not fully covered by Western concepts of humanism: see Tang, Renwen jingshen zhi chongjian (Hongkong), pp. 591-592. He identified a passage from the Yijing as an early occurence of the word "renwen," but he did not present an interpretation of it; see ibid., pp. 590, 594.

Ibid., pp. 596-597. 
thought, Confucian humanists apparently made no effort to suppress it, but rather tried to understand the respective "psychological, personal, cultural and historical background" and in this way potentially overcome their own hostile attitude. ${ }^{84}$

This insistence on the undogmatic attitude of Confucian humanism is rather typical of the ambivalence that characterizes Tang's reflection on nation and national culture in general. For all its culturalist and essentialist simplifications in favor of "Confucianism," Tang's hypostasis of national culture and its humanistic "main current" does not amount to a traditionalist reaction. He neither assumed that there is an unbroken normative validity of traditional culture in the modern world, nor did he subscribe to the idea of a return to a safe haven of tradition. The cultural nation, in his eyes, did not persist in eternally valid, fixable elements of national culture or a rigid arrangement of customs and values from a Confucian orthodoxy. The normative relevance of the "main current," according to Tang, could not be taken for granted. It was a matter of reflexivity which meant that it had to be reconstructed without any claim to a historically incommutable essence. The historical transmutations and changing expressions of the "main current" have to be retraced from within a horizon spanning the modern world and its exilic dimension. In other words, the "main current" itself cannot be isolated from this horizon of interpretation in order to constitute an objective truth. The reader of those texts in which Tang reflects on the topics of China's national culture, the exilic situation and the process of modernity may indeed find Tang to be a hermeneutic thinker: He maintained that the "main current" was not simply a result of interpretation, but an integral part of the cultural horizon of a community of interpreters, that is, a historical context of the act of interpretation per se. In accordance with this hermeneutic approach, the humanistic-cultural "essence" or "main current" is to be understood as a sort of normative web that ceaselessly transforms itself in light of new identifications, interpretations and appropriations. ${ }^{85}$

84 Ibid., p. 598 .

85 This concept of cultural essence differs from the concepts which were presented in the Journal of National Essence (Guocui Xuebao 國粹學報) after 1905 and by members of the Southern Society (Nanshe 南社) after 1909. Those concepts focused on philological and literary traditions, and not on "Confucian" traditions. Furthermore, they did not assume that the national essence itself might be subject to historical change. Zhang Taiyan's concept was a notable exception in both regards, even though he refrained from singling out Confucian traditions. Later on, the circle of authors of the Critical Review (Xue Heng 學衡) also identified a national essence of different contents; see Furth, "Culture and Politics in Modern Chinese Conservatism," p. 31; Schneider, Wahrheit und Geschichte, pp. 82, 109-112; Laitinen, Chinese Nationalism in the late Qing Dynasty, pp. 116-118. 
The hermeneutic approach thus imposed limits on the essentialist extent of the interpretation of humanistic culture and its Confucian "main current." On this basis, the question as to whether "Western" thought could be removed from the horizon of interpretation altogether in modern times never even arose. ${ }^{86}$

\section{Cultural Patriotism}

A topic that did arise in this context was the coping of individuals with the fateful experience of exile. Tang's concept of interpretation took account of distinctly exilic experiences by inscribing the exile into a comprehensive horizon of interpretation and meaning. The constitution of the hermeneutic subject, i.e. the individual interpreter of the "main current," was understood as inextricably linked to the exilic situation, that is, the specific context of the process of interpretation itself. The individual suffering in exile was thus infused with hermeneutic relevance: The manifesto of 1958 declared that only by virtue of the particular experience of intellectual and emotional isolation-shared by the exiled intellectuals at the beginning of their time as emigrants - was it at all possible to "once again" and in a "fundamental manner" turn to "Chinese scholarship and culture, as well as the problems of China." Tang also suggested that the "problems" of China and its culture are only clearly recognized in exile and, moreover, that "true wisdom" emerges out of the "suffering" (in exile). This suffering, in other words, gave rise to an intellectual openness, or, as Tang called it, "a transcendental and all-encompassing state of mind" that had not been present "ten years earlier." In Tang's view, what was at issue here was the liberation of the interpretation of national culture from a "fixed pattern of life" and an overcoming of the "narrowness of one-sided opinions." 87

Tang emphatically defended the hermeneutic openness of his understanding of national culture against determinism in the historiography of China's national history. The nation's historical course as a whole was in no way to be determined by the hermeneutics of a national-cultural essence, nor predetermined in any other way. The "historical future" has no "particular imperative direction," and even if there were such a thing, Tang explained, no one would

86 On a programmatic statement in favor of a broad inclusion of Western thought and traditions: see e.g. Zhang, Zhongguo wenhua yu shijie, pp. 46-59.

87 Ibid., p. 4; see also: Tang, Zhonghua renwen yu dangjin shijie bubian, Vol. 9, p. 478. Tang was undoubtedly aware of Mencius' claim that personal suffering was an impetus of individual cultural productivity (cf. Mengzi vi B.15). 
be capable of recognizing it. The course of national history was unpredictable. Tang's understanding of the "tragedy" of the Chinese nation thus had the status of an interpretation, not a scientific diagnosis or prognosis. Equally unpredictable were the duration of exile and the "methods" by which the condition of exile might be overcome. It was precisely these unknowns that triggered the sense of despair in exile, which, Tang stated, could not be eluded. The exiles could not truly find "hope" or "trust" in the promises for the future provided by a nationalist ideology; instead they had to engender such positive sentiments from within themselves. A prerequisite for this, in the first instance, was a "true to life experience" of despair, far beyond the dazzling allure of ideology. Only then could a thorough reflection on the reasons for despair begin that would allow autonomous individuals to establish "ideals" and form their own "will," provided that their reflection entailed some sort of meditation on the history and culture of China in a state of "emotionally reminiscent gratitude." Here, Tang's language once again appears to suggest a nationalist attachment to China, but he in fact took great pains to point out that normative insights ("the ideals") could only be gained in conditions of "absolute liberalism." Thus what is true for the process of reflection is also borne out in practice: Neither the cultural nor the political activities that befit normative insights are predetermined. ${ }^{88}$

The distinction between nationalism and (cultural) patriotism is crucial for understanding the basic orientation of modern Confucianism. For Tang, the highest purpose of China's humanistic culture was not tied to the nation or the nation-state. His modern Confucianism was indeed not nationalistic, but rather an expression of a conservative, defensive type of cultural patriotism. ${ }^{89}$ As a Confucian patriot in exile, Tang strove above all to preserve China's humanistic culture. Such preservation should, of course, secure the continuation of China's national culture and thus guarantee the existence of a Chinese nation. But Tang was unwilling to subject China's humanistic tradition to the nationalist cause of preserving the nation for its own sake. He did not con-

88 Tang, Shuo Zhonghua minzu zhi hua guo piaoling, pp. 47, 49-54, 59-6o.

89 Tang did not use the Chinese term “aiguozhuyi” 愛國主義, which is the common translation for "patriotism," most likely because "aiguozhuyi" is part of the ideological vocabulary of the PRC. However, his brand of cultural patriotism is consistent with European concepts of patriotism from the 19th century, when patriotism was increasingly related to concepts of nation and finally served as a concept countering ideas of an expansive nationalism. On patriotism and its link to cosmopolitism and Enlightenment in Europe of the 18th century: see Alter, Nationalismus, p. 12; Giesen, "Vom Patriotismus zum Nationalismus," p. 273; Kluxen-Pyta, Nation and Ethos, pp. 163-165. 
template saving the nation and the nation-state at the price of sacrificing humanistic ideals. Nor would he have subscribed to an agenda of cultural nationalism that essentially uses cultural symbols, traditions, or even myths to give expression to a nationalist call for mobilization. Tang's reconceptualization of Confucian humanism thus stands in stark contrast to Liang Qichao's nation-state-centered Confucianism. Liang had introduced such an approach prior to the founding of the republic during the 19oos. In doing so, he relegated Confucianism from the sphere of the imperial cult of state to the sphere of the citizen's political and private virtues and values. In Liang's scheme, Confucianism would henceforth fulfill a complementary function within the nation-state. ${ }^{90}$

Tang also maintained a critical distance from the unifying nationalism of the GMD regime. His concept of national culture differed considerably from the sort of (Confucianized) nationalism which the GMD installed in the 1950s and 1960 s as the ruling ideology in Taiwan. It is therefore not surprising that he clearly distinguished his Confucian cultural patriotism from Sun Yat-sen's brand of nationalism and Sun's claim that the nation-state requires ethnic homogeneity in order to safeguard its existence. According to Tang, such a premise amounted to nothing less than an elimination of the idea that the citizens shall decide to strive for unity within a state by reasonable choice. In bolstering his argument against Sun Yat-sen's ethnic nationalism, Tang contended that national consciousness does not emerge as a direct, "natural" upshot of common origins, language, beliefs, traditions or culture, but indeed arises from the individuals' reasoned "self-awareness" of these commonalities. He therefore insisted that the citizens develop their national consciousness in terms of a "rational" construct. ${ }^{91}$

What is more, Tang's Confucian cultural patriotism entailed a Pan-Asian outlook as well as an insistence on the cosmopolitan ideal of a world citizen. In this context, Tang's education ideal for the New Asia College, which he declared with much pathos, is highly illuminating. He exhorted the students not to content themselves to be simply citizens of Hong Kong, for after all, this was what they were purely by virtue of living in Hong Kong. The role of the New Asia College was to support the students in becoming "impressive Chinese [personalities]" and "world citizens of colossal [intellectual] stature." This congruence of patriotic and cosmopolitan personality ideals was

9o On Liang's notion of Confucianism in relation to his concept of the state, see e.g. Machetzki, Liang Ch'i-ch'ao und die Einflüsse deutscher Staatslehren auf den monarchischen Reformnationalismus in China nach 19oo, pp. 56, 59.

91 Tang, Zhongguo renwen jingshen zhifazhan, p. 183. 
characteristic of the quest to enable the (exilic/modern) self to achieve authenticity. Tang advised students of New Asia College to focus their research on Chinese and Western humanism, philosophy and literature. Students might study Confucius, Menzius, Xunzi and $\mathrm{Zhu} \mathrm{Xi,} \mathrm{as} \mathrm{well} \mathrm{as} \mathrm{the} \mathrm{poets} \mathrm{Du}$ Fu and Li Bai, and, equally important, Plato, Aristotle, Kant, Hegel, Dante and Shakespeare. All of these illustrious names were apparently considered to be outside Hong Kong's narrow intellectual spectrum. The "intellectual intentions" of the New Asia College were, as Tang suggested, not limited to Hong Kong, but included China and the entire world. ${ }^{92}$ Significantly, Tang was convinced that the renewal of China as a cultural nation could only succeed if Western civilization was even appraised in those core areas of Chinese culture, in which individuals attain the "intellectual determination" to save the nation. ${ }^{93}$

The Asian perspective should not be dismissed, however. Bringing "new life" to Asian cultures, including Chinese and Indian cultures, which were older than European cultures, was important. This was particularly true, as Tang asserted, given that Asia had been degraded as Europe's largest colonial area over the previous 200 to 300 years. But despite Asia's backwardness in terms of scientific and industrial-technological developments, one was not to assume that the entire "spirit" of Asian cultures was backward. ${ }^{94}$ Notwithstanding this essentialist reference to Asia's cultural spirit, Tang's culturalist concept of a new Asia stopped short of proposing any ideas of ethnic homogeneity of a "yellow race." It clearly differed in this respect from previous forms of PanAsianism, which became popular in Japan in the 1890 s and were propagated by Liang Qichao between 1896 and 1899. Tang's interpretation of a "new Asia" was closer to Liang's post-1919 concept of cosmopolitism, in which Liang emphasized that each individual member of the Chinese nation has responsibilities toward world civilization. ${ }^{95}$ It was in relation to this cosmopolitan framework that Tang referred to a singular Asian culture and a new Asia, and the same may be said of other Pan-Asian notions, such as "Eastern/Oriental cultures" (Dongfang wenhua 東方文化) or "people from the East/Orient" (Dongfangren 東方人). By "people from the East/Orientals" Tang meant Chinese, Japanese

92 Tang, Zhonghua renwen yu dangjin shijie bubian, Vol. 9, pp. 505-506; cf. also p. 488.

93 See, for example, Zhang, Zhongguo wenhua yu shijie, pp. 4-5, 18, 32-35, 41-42.

94 Tang, Zhonghua renwen yu dangjin shijie bubian, Vol. 9, pp. 457-458.

95 Huang, "Liang Ch'i-ch'ao: The Idea of the New Citizen and the Influence of Meiji Japan," pp. 8o-82 (on Pan-Asianism); Tang, Global Space and the Nationalist Discourse of Modernity, pp. 192-193 (on cosmopolitism). 
and Koreans. He distinguished "true" from "ordinary" Chinese, Japanese and Koreans and assumed that there was a common attitude toward life among "people from the East/Orientals," which he quite schematically distinguished from Western attitudes with respect to inwardness and quietness (Eastern) as well as outwardness and activity (Western). ${ }^{96}$

Nevertheless, Tang's cosmopolitism was entrenched in (post-)colonial PanAsian ideas about the global relevance of East-Asian cultures in the modern world. His depiction of the current differences between Western and Asian modernization is at times rather crude and also belies his own sophisticated explorations into Western philosophy. ${ }^{97}$ The reasons for the ambivalence of Tang's intellectual open-mindedness toward Western civilization and his personal resentment towards "the West" most likely stem from profound feelings of inferiority. Unlike most of his contemporaries, Tang gave frank testimony about his inner conflict: He loathed neither Western thought nor cultural traditions, but deplored the fact that most people when he travelled to Europe and the United States in the late 1950s did not show him much respect or interest. Rather than asking him for his opinion of Western cultures, they treated him instead like some insignificant traveler. He concluded that most Europeans and Americans do indeed look down on visitors from East Asia, as if they were visitors from an inferior region. ${ }^{98}$ Yet this estrangement is not merely a consequence of suspicions he had of Western cultural imperialism. When travelling in the West, he astutely observed his own reactions to personal encounters he witnessed between people from Western and East Asian countries. He professed to having had some resentment even with regard to physical differences. For instance, he recalled his discomfort in noticing how an East-Asian person of short stature was forced to look up to a taller person from the West when shaking hands. He felt similarly uncomfortable when he observed that the bridge of a Westerner's nose was higher and his eyes more deeply set. He even suspected that it was also perhaps why Westerners had been so proud and the East Asians so submissive in their personal encounters during the second half of the 19th century. ${ }^{99}$

96 See his travel notes while visiting Korea in 1965: Tang, Zhonghua renwen yu dangjin shijie bubian, Vol. 10, pp. 354, 367. Similar juxtapositions of Eastern and Western cultures and attitudes had been debated in China since the mid-1910s (see influential writings by Du Yaquan 杜亞全, Li Dazhao 李大釗, Chen Duxiu and others).

97 Tang, "The Reconstruction of Confucianism and the Modernization of Asia," p. 365.

98 Tang, Zhonghua renwen yu dangjin shijie bubian, Vol. 10, p. 364.

99 Ibid., p. 349 . 
Apart from these psychological issues, Tang had other reasons for being concerned about the prejudiced view of East Asian culture. A loss of normative validity for what he called "East-Asian traditional culture" would have serious consequences for modernization. Given the conception of modernization as concerted collective action based on conscious cultural transformation, a postcolonial self-deprecation in East-Asian countries would have had disastrous consequences if allowed to go unchecked. It might indeed have undermined the belief that the process of modernity could be reined in by firmly establishing "cultural" forces within modern societies. Tang thus underscored the need for a reinterpretation of (East-Asian) culture and advocated a "spiritual reawakening," a "revival" of the "innate spirit" of a culture in a "new form."100 This "spiritual reawakening," he suggested, should also take the form of a "spiritual renewal on a daily basis" in the education and cultural ideals as well as in the ideals of the New Asia College. ${ }^{101}$

Contemporary Japan was an exemplary case in this regard. In an article from 1971, Tang identified the country's potential to develop its "traditional culture" within the modern world. ${ }^{102}$ He believed that Japan so far has been more successful than Korea, the communities of overseas Chinese, European countries and the United States in preserving many elements of a traditional "cultural way of life." This comprised a form of ethical life characterized by the prominence of arts, literature, ethics, religion, and wisdom in everyday life. Tang added, however, that Japan was also now struggling with the effects of industrialization and a growing tendency among Japanese to take up Westernstyle attitudes of "utilitarianism." There were even signs of a gradual demise of traditional ethical life among the "lower stratum" of Japan's industrial society and in the student protests of 1969 some of which he witnessed when visiting in Kyoto. But he apparently only took note of these developments in passing and remained optimistic overall with respect to Japan's ability to conquer this cultural "crisis." 103

Such optimism is symptomatic of a vision of modernity based on a sugarcoated Pan-Asian construction of "East-Asian" culture. For all his astute observations on the downsides of modernity, Tang seems to have been oblivious to the deleterious effect of militant Japanese Pan-Asianism and its euphemistic "East-Asian" rhetoric. Indeed, he had little apprehension when visiting

\footnotetext{
100 Tang, "The Reconstruction of Confucianism and the Modernization of Asia," p. 361.

101 Tang, Zhonghua renwen yu dangjin shijie bubian, Vol. 9, p. 459.

102 Tang, Zhonghua renwen yu dangjin shijie, Vol. 8, p. 212.

103 Ibid., pp. 208-210.
} 
Japan in the late 1950s, as evidenced by his letters to his wife. ${ }^{104}$ He showed no interest in analyzing the formation of Japanese militarism in the context of modernity — a topic he treated only occasionally and never in-depth. ${ }^{105}$ Yet it has not always been a case of too little interest in the matter: On August 1, 1957, Tang delivered a speech at Asia University in Tokyo (founded in 1941) on "The progress and self-consciousness of humanity" in which he deigned in a vexing manner to play down the Japanese war crimes committed in China during the Second World War, stating that the Sino-Japanese relations had turned into an "unfortunate relationship." He assumed that this "unfortunate" state would not last forever, quoting from the famous Chinese novel Water Margin (Shuihu Zhuan 水狺傳) the phrase "no fighting, no friendship," and adding that "quarrels among elder and younger brothers are perhaps due to the fact they have a relationship in which the feelings [for each other] are too good"(!). ${ }^{106}$

Overall, it seems that Tang was not especially interested in Japan as such, but more in its promise of a better modernity. Japan had seemingly been very successful in establishing an industrialized society while preserving traditional forms of an ethical life. Tang suggested that this was the upshot of a conscious effort by the Japanese, and not just the result of a unique and fortunate historical constellation. In other words, post-war Japan symbolized the human ability to consciously withstand the negative forces of modernity by making specific choices related to humanistic culture. This constellation had an even more intimate relevance from the Chinese perspective insofar as Japan in many ways was portrayed as just another, albeit more successful, "China." Tang was in fact convinced that the Japanese still orientated their choices concerning humanistic culture and forms of ethical life toward the Chinese model, taken from the periods of the Tang and the Song Dynasties: So it was a "Chinese culture on a small scale" that was still extant in Japan and which, moreover, never collided with the exigencies of modernization. Tang added, tellingly, that it should be even easier for the Chinese than it was for the Japanese to achieve such a form of modernization. ${ }^{107}$

104 Tang, Zhi Tingguang shu, pp. 330-331 (letter dated February 22nd, 1957), p. 334 (letter dated February 23rd, 1957).

105 See, for example, Tang, Zhonghua renwen yu dangjin shijie, Vol. 8, p. 210, Tang, Zhonghua renwen yu dangjin shijie bubian, Vol. 10, p. $35^{8}$.

106 See Tang, Zhonghua renwen yu dangjin shijie bubian, Vol. 10, pp. 312-313.

107 See an interview by Tang in the Mingbao from 1974: Tang, Zhonghua renwen yu dangjin shijie, Vol. 8, pp. 313, 327 . 
The depiction of contemporary Japan as a model for a future China stands in stark contrast to the bleak situation of the Chinese in the 1950s and $1960 s$. It seems that when emigrants like Tang were forced to accept the unfortunate truth that the type of Chinese nation-state which they preferred was neither in the making on the Chinese Mainland nor in Taiwan, the appeal of Pan-Asian ideas and the Japanese model grew considerably. The latter apparently served the purpose of compensation for the loss of hope of rescuing the Mainland from communism: In exile, the intellectual struggle for the political and cultural emancipation of Asia, together with an orientation towards an emerging world culture in East Asia, gradually supplanted the hopeless struggle to save the Chinese cultural nation on the communist-ruled Mainland. If the Chinese contribution to the modernization of East Asia and to the modern world more generally was based on a reconstruction of China's humanistic traditions, the exilic space might indeed become a bridgehead in the struggle for future modernization. China's responsibility toward the modern world would then take its due course. As Tang envisioned in a letter to his wife in 1965, the reconstruction of China's humanistic traditions would first encompass Japan and Korea and then India, Europe and the United States. ${ }^{108}$

\section{Defending Authenticity}

Notions of reconstructing Chinese and (East-)Asian cultures, along with the idea of recovering a humanistic "main current" or a cultural "spirit," are highly charged with normative meaning, not only in the context of Tang's diagnosis of modernity, but also of his reaction to the exilic experience. In reflecting on exile, Tang assumed that coping with the exilic fate requires individuals to situate their own biographical narratives and actual lifestyles in terms of a humanistic-cultural continuum. In other words, only those exilic individuals who succeed in identifying themselves as historically, culturally, and ethically situated subjects might be able to attain a sound notion of personal selfhood.

Tang applied here a pathos-rich language of authenticity with phrases such as "true self-awareness" and a "true self:" human beings, who were called to life as "biological beings," might achieve their authentic "existence" only by clearly recognizing their "true reality." This required them to absorb "instruction and nourishing" through the medium of the language, history, culture,

108 Tang, Zhi Tingguang shu, p. 488. 
customs and traditions of their nation. ${ }^{109}$ Such a process required that the normative significance of the "past and present" of the national culture be "conserved." Authentic self-awareness was thus related to the (re-)interpretation of the national culture itself - that is, by acts of interpretation in which the individual is already embedded through his or her very existence:

But as the ecumene-as-family (tiaxia yi jia 天下一家) has not yet been reached, the individual can only strive to authentically live and exist in the past, present, and future of his own state, nation and historical culture [in order to] set the self at ease and establish destiny (an shen li ming 安身立命). ${ }^{110}$

Tang's culturally conservative yet effusive language tends to mask the criticalemancipatory substance of his concept of authenticity of the self: Even though he assumed that the perpetuation of national culture can occur in a "natural" or "direct" manner and thus, to a certain extent, without critical reflection, cultural "conservation" was not to be misunderstood as an uncritical absorption. Rather, it required a guiding conservative principle of conscious reappropriation. Tang emphasized that because each decision about the transformation of elements of national culture was difficult by itself, conscious changes should only be allowed in cases in which there was no doubt that those elements called into question are now "without value."111 This preference for a critical, albeit defensive, stance towards national culture, and not for a blind apology, was also apparent in the announcement that it would "self-evidently" be better if all individuals were to "analyze and reflect on" the national culture, instead of simply following established habits. ${ }^{112}$ The highest authority with respect to the personal adoption of the national culture was therefore the individual

109 Tang, Shuo Zhonghua minzu zhi hua guo piaoling, pp. 8, 11. In his late work Shengming cunzai yu xinling jingjie, Tang further developed this notion of the embeddedness of the subject. He introduced the notion of so-called "horizons" of the subject's interrelation with its physical, historical, intellectual, emotional and spiritual environment. Only in relation to these horizons could the human being acquire self-awareness and subjectivity, as well as views of life, world views etc. For a brief introduction to the idea of "horizon" in Shengming cunzai yu jingjie, see Liao, “Tang Junyi 'panjiao lilun' de chubu kaocha," p. 39.

110 Tang, Zhonghua renwen yu dangjin shijie bubian, Vol. 9, p. 484; cf. Shuo Zhonghua minzu zhi hua guo piaoling, p. 24.

111 Tang, Shuo Zhonghua minzu zhi hua guo piaoling, p. 8.

112 Ibid., pp. $12,16$. 
"conscience" (liang xin 良心). It was here that the conserved elements of national culture must stand the test. ${ }^{113}$

The freedom of conscience was a necessary, albeit not sufficient precondition for authentic self-awareness. Two more components were required, namely, the expression and the situating of the self. ${ }^{114}$ In Tang's philosophy, expressivity plays a crucial role in coping with intellectual, emotional, and social isolation in exile and in the modern world in general. The creation of opportunities for overcoming this isolation presupposes, according to Tang, that individuals retain the ability to express themselves as members of a national-cultural community whose ongoing interpretations of the humanistic "main current" are bound together with a sense of cultural patriotism. Individuals would thus affirmatively identify certain collective ties in society and the state as integral elements of their own historical and biographical narratives. Otherwise, there would be no way for them to cope with their unique experiences of alienation, except by falsely retreating into purely subjective inwardness. In Tang's modern, romantic-expressivist notion of authenticity, the individual's self-awareness requires, in order to become authentic, opportunities for expression in social contexts. Here, Tang presumes that the very expression of such self-awareness involves a "place" (chu 處) where commonality can be experienced. Tang relates this to the exilic situation in a passage from 1961:

[Only] if we would have been formerly completely without ideals existing in our consciousness with respect to the state and politics, could we also be without suffering [now that we] see all kinds of facts that are in disagreement with them. But amidst this [current situation] men must strive for a place where [they] can express confidence and hope, and, in turning our heads in such manner, [we may] become aware of the existence of these ideals. I can have any ideal and I can then begin for myself to put this ideal into practice. What I can put into practice, [other] people can [put into practice] too. In that case, this place has then already become the place where I may express confidence and hope. [...] This is

113 Ibid., p. 20. In this context, see also Luo Yijun's commentary on Tang's understanding of "self-awareness:" Luo, "Shidai beiqing yu wenhua xinxin," p. 57.

114 For the following analysis of Tang's interpretation of authenticity, Hartmut Rosa's critical analysis of Charles Taylor's conception of authenticity proved very thought-provoking: see Rosa, Identität und kulturelle Praxis, pp. 24-25, 93-94, 149-155, 191-212. 
then also the place where we all may, in any environment, express confidence and hope. ${ }^{115}$

Exile would thus lose its character as a non-place and the exilic subject could situate him- or herself within the long continuum of interpretation and appropriation of China's humanistic culture. Consequently, Tang saw the authentic self being realized in "concrete human beings" (juti de ren 具體的人) and concrete world citizens, who are able to preserve their moral autonomy and to assure themselves of their manifold collective ties, including their affiliation to a state or a nation and belonging to a cultural tradition. Only in this way could they achieve self-esteem, or in Tang's words: an "independent personality of colossal stature."116

To be sure, these "independent personalities of colossal stature" would neither reduce China's humanistic traditions to a mere context, nor scrutinize them as rigidly fixed objects. Instead, they would realize that national culture emerges only in the process of interpretation itself and consequently finds its "place" in the interpretation. In terms of coping with the exilic experience, this re-conceptualization of national culture is of crucial importance. It exemplifies the conviction that the Chinese nation, while in danger of immediate extinction after 1949, might still survive in the hermeneutic place of its renewal through exilic cultural patriotism. This vision of a historical and normative continuity in interpretation has itself a compensatory effect insofar as it posits the longue durée of interpretations, thereby temporally expanding the experience of historical time and bridging the generational isolation experienced in exile. It is at this point that the exilic hermeneutics of the national culture and the hope for its salvation converge in modern Confucianism's sense of mission.

In contrast to the self embedded in the context of national culture, Tang elucidated the characteristics of a self that is not situated in the hermeneutics of national culture. What he had in mind here above all are "pure believers," who seek their salvation by placing unmitigated trust in God or in an eventual paradise, ${ }^{117}$ and "abstract world citizens," who advocate a false and empty universalism. According to Tang, the latter was demonstrated, for example, in an interpretation of the old ideal of "the ecumene as one family," the locus

115 Tang, Shuo Zhonghua minzu zhi hua guo piaoling, pp. 54, 59 (for the sentence after the omission). Spatial topics with respect to the subject of individual self-awareness figured prominently in the philosophy of the Kyoto school. However, I could not locate any substantial reference from Tang to discussions of this topic within the Kyoto school.

116 Ibid., pp. 56, 58 .

117 Ibid. 
classicus of which can be found in the Record of Rites (Liji 禮記; Chap. “Li yun" 禮運). Tang wholly disagreed with those who accept this ideal out of a yearning for China's absorption into a "culture of humankind," which would entail the complete disappearance of particular national cultures. Although he did not mention any names, he obviously opposed Kang Youwei's idea of the uniformity of mankind, elucidated in The Book of Great Uniformity (Da tong shu 大同書). It had an air of admonition when Tang stated that such misguided universalistic notions did not constitute a moral problem as long as they are solely expressed as private opinions. ${ }^{118}$

Yet the situating of the self in the hermeneutics of the national culture was also threatened in exile by those positivist currents in the social sciences and the humanities that Tang declared philosophical war against. He again mentioned no names, but remarked nonetheless that some within the emigrant elite engaged in the humanities asserted a positivist concept of culture under the influence of Western schools of thought. The positivist currents falsely conceive of "Chinese culture" as a conglomeration of relics from a lost culture and reduce the interpretation of culture to a crude dichotomy of enquiry between subject and object. This stands in stark contrast to Tang's own idea of an "authentic" understanding of national culture which must take as its hermeneutic horizon the humanist "main current" of China's national culture. As we have seen, Tang expected the interpreters to perceive the "main current" not as a mere object of scrutiny, but as belonging to their own horizon of understanding. An "authentic" interpretation, therefore, cannot claim to represent objective truth. He consequently argued that positivist approaches failed to live up to their own claims of objectivity. ${ }^{119}$ Tang did not turn against these currents merely because they were anti-traditional. Their positivist tendency to objectify "culture" and hence isolate it from the individual subject was effectively a mirror-image of exilic isolation. He located this aberration in contemporary sociology, psychology, historical studies and cultural anthropology and traced

118 Zhang, Zhongguo wenhua yu shijie, pp. 7, 28.

119 Zhang, Zhongguo wenhua yu shijie, pp. 9-11. This critique explicitly comprised the historical studies of the so-called "reorganization of the national heritage" (zhengliguogu 整理 國故), which was one of the dominant tendencies in historical research from the 1920 s onwards. Its representatives, among them Hu Shi, claimed to lay the groundwork of a new, "scientifically" accountable cultural and social consciousness in China by conducting comprehensive scientific research in Chinese history; see Fröhlich, Staatsdenken im China der Republikzeit (1912-1949). Die Instrumentalisierung philosophischer Ideen bei chinesischen Intellektuellen, pp. 335-336. 
the reasons for the anomalous objectivism back to untenable epistemological stances in the concerned academic disciplines. Positivist approaches in these disciplines, he suggested, had restricted themselves to the detection of supposedly objective facts, which then must be accepted as "reasonable."120

However, this apparently academic critique of the theoretical and methodological implications of rampant objectivism in the humanities did not constitute Tang's actual line of attack. The real bone of contention was the objectivist pretense of identifying "true values." The positivist appropriation of "cultural theory" accorded the human being the position of an ahistorical subject and hence rendered it impossible for the individual to create an authentic form of self-awareness. As an "abstract self," the individual would no longer command any "historical reality." It was the status and the significance of the "tragedy" of the Chinese nation that was really at stake in dealing with the untenable objectivism described above. Inasmuch as positivist approaches "rationalized" the ostensibly imminent demise of China's national culture, the awareness of the tragedy dissolved. This would have severe consequences for the individual's chances of attaining an authentic self. ${ }^{121}$

Yet by contrasting the objectivist approach to China's national culture and history with what he called an attitude of "empathic understanding" (tongqing de liaojie 同情的了解),122 Tang himself exceeded the limits of philosophical hermeneutics. He in fact demanded much more from a sound interpretation of national culture than just a hermeneutical awareness of its own historical and practical boundedness and a reflection on the Wirkungsgeschichte (effective history) of seminal writings. For Tang, the interpreters should in addition take on the role of performers of national culture and be willing to infuse their intellectual interest with an emotional attachment to their "own" national

120 On sociology, psychology, historical studies and cultural anthropology, see Tang, Shuo Zhonghua minzu zhi hua guo piaoling, p. 18. On the problem of objectivist aberrations, see ibid., pp. 18, 28.

121 On the rationalization of the "tragedy," see Tang, Shuo Zhonghua minzu zhi hua guo piaoling, pp. 7, 18; on the epistemological position of the subject of interpretation, see ibid., p. 12; on the "abstract self" see ibid., pp. 18, 28.

122 The concept of empathic understanding had been current in Chinese reflections on historiography at least since 1930, when the German-trained historian Chen Yinke called for an "empathetic understanding" of the historical manifestations of China's "national spirit" (e.g. in Chen's article on the first volume of Feng Youlan's History of Chinese Philosophy); see Schneider, Wahrheit und Geschichte. Zwei chinesische Historiker auf der Suche nach einer modernen Identität für China, pp. 135-136; Schneider, "Reconciling history with the nation? Historicity, national particularity, and the question of universals," p. 127. 
culture. "Authentic understanding" would hence require empathy and respect for the national culture. Thus, for all Tang's critique of dogmatism and positivism in the humanities, he himself opened the door to a notion of interpretation that is only partially reconcilable with philosophical hermeneutics. ${ }^{123}$

The considerable strain placed on hermeneutics in Tang's exile philosophy is to a large degree due to his insistence on the authentic self-awareness of a historical self situated in national culture:

Here, we have to clearly recognize, first of all, that the life of human beings (ren zhi shengming 人之生命) does not exist solely due to its abstract probability, but exists due to its genuine reality. God and nature may create me in any society or territory; this is merely an abstract probability from [the time] before I have been created. But within this abstract probability, I am indeed without a life of authentic existence (zhenshi cunzai 真實存在). My life of authentic existence still exists in that I am created as a member of the Chinese nation and accomplished by receiving an education and upbringing in the languages, culture and social customs of China; and this whole education and upbringing as well as the Chinese nation out of which I am created cannot be distinguished from the existence of my life. Whether I am self-conscious of that from which I have been created and about the whole existence of education and upbringing is in fact the same thing as whether I am truly self-conscious about the existence of my life. ${ }^{124}$

This passage reads like a nationalist avowal which also borders on denying selfconsciousness to those who refuse to identify with China's national cultureeven more so because of its almost intimidating tone. One cannot brush the statement easily aside, especially because it is hardly a unique occurrence in Tang's writings of the 1950 s and 196os. The question therefore arises once again of whether Tang crosses the line from a culturally conservative patriotism to outright nationalism. The picture remains ambivalent given Tang's aforementioned diffidence with respect to the ethnic nationalism of the GMD and his unswerving insistence on "absolute liberalism" for individuals to choose their own ideals. To help clarify this ostensible inconsistency, it should be noted that Tang made the above statement in a text that explicitly deals with the problem of exilic life. From this perspective, his message appears to be much less intimidating than defensive, stemming from an existential concern that the

123 Zhang, Zhongguo wenhua yu shijie, pp. 10-11.

124 Tang, Shuo Zhonghua minzu zhi hua guo piaoling, p. 11. 
experience of emigration might deny the individual any awareness of historical belonging. One of the fundamental lessons of Tang's exilic philosophy is that an isolated individual cannot attain such awareness. To be meaningful to the exilic individual, the awareness of belonging to China - even if this China is only present in the form of interpretations of national culture-requires that the individual be able to assure him- or herself that other individuals share the same awareness and similarly identify themselves as "true Chinese."125 Without this shared awareness among the emigrants, the exilic space inevitably turns into a non-place.

In exilic thought, avoiding such a vacuous existence and the demise of the Chinese nation necessitated, as we have seen, a concept of national culture in which its "main current" was dissociated from the territorial boundaries of the contemporary Chinese nation-states. According to this imagined transgression of external boundaries that were imposed politically and intellectually, the nation and its culture would now be able to exist outside the two Chinese nation-states on the Mainland and on Taiwan. Even outside of these territories, however, there were intellectual boundaries imposed by modern, "(self-)colonizing" tendencies which threatened the continuation of the "main current." As a consequence, the Chinese nation had to retreat behind "inner" boundaries, which were continuously drawn and redrawn through reflection and reinterpretation of the national culture. ${ }^{126}$ Tang reflected on the "inner boundaries" in an allegorical way: He professed that, as an emigrant, he could only seek shelter in Hong Kong, and even if his life in exile was an unhappy one, he could still reach Shenzhou 神州 in his "dream-ego."127 Shenzhou traditionally represents two visions: A mythological place inhabited by immortal beings and a territory from which the civilization of the Chinese empire emerged. By expressing his longing for Shenzhou, Tang asserted that under the current conditions of exile and modernity his subjective yearning for transcendence had not yet been obliterated and his identification with China's national culture had not yet been annihilated.

\footnotetext{
125 Ibid.

126 On the concepts of inner and outer boundaries, see the analysis of Fichte's Reden an die deutsche Nation in: Kallscheuer, "Deutsche Kulturnation versus französische Staatsnation? Eine ideengeschichtliche Stichprobe," pp. 156-161.

127 Tang, Shuo Zhonghua minzu zhi hua guo piaoling, p. 29.
} 